\title{
An Unusual Late Aboriginal Assemblage from the Wilson Site (41SS186), San Saba County, Central Texas
}

Charles A. Hixson

Llano Uplift Archeological Society

James K. Feathers

Department of Anthropology, University of Washington

Follow this and additional works at: https://scholarworks.sfasu.edu/ita

Part of the American Material Culture Commons, Archaeological Anthropology Commons, Environmental Studies Commons, Other American Studies Commons, Other Arts and Humanities Commons, Other History of Art, Architecture, and Archaeology Commons, and the United States History Commons

Tell us how this article helped you.

This Article is brought to you for free and open access by the Center for Regional Heritage Research at SFA ScholarWorks. It has been accepted for inclusion in Index of Texas Archaeology: Open Access Gray Literature from the Lone Star State by an authorized editor of SFA ScholarWorks. For more information, please contact cdsscholarworks@sfasu.edu. 


\section{An Unusual Late Aboriginal Assemblage from the Wilson Site (41SS186), San Saba County, Central Texas}

\section{Licensing Statement}

Reproduction, posting, transmission, or other distribution or use of the Journal volume, individual article or any portion of the material therein, in any medium, is permitted strictly for personal, non-commercial purposes via a personal-use exemption under a Creative Commons license granted by JTAH.org, Inc. This license exemption requires, as a condition of its granted permission, proper credit be attributed to JTAH.org as copyright holder (e.g., Journal of Texas Archeology and History.org @ 2017). No part of this publication may be reproduced, posted, transmitted, or otherwise utilized or distributed in any form by any means or method for commercial purposes without the express written consent of the Publisher. Inquiries should be addressed to JTAH Publisher, Suite 307, Box 361, 5114 Balcones Woods Drive, Austin, Texas, 78759.

The Journal of Texas Archeology and History.org is an organization dedicated to furthering research, education and public outreach in the fields of archeology and history concerning Texas and its bordering states of Louisiana, Arkansas, Oklahoma, New Mexico and Northern Mexico; a region we call the "Texas Borderlands." The J.T.A.H. is collaborating with the Index of Texas Archaeology and S.F.A.S.U. to distribute their publication library to the general public via free and open-access channels. Visit www.JTAH.org to submit an article. 


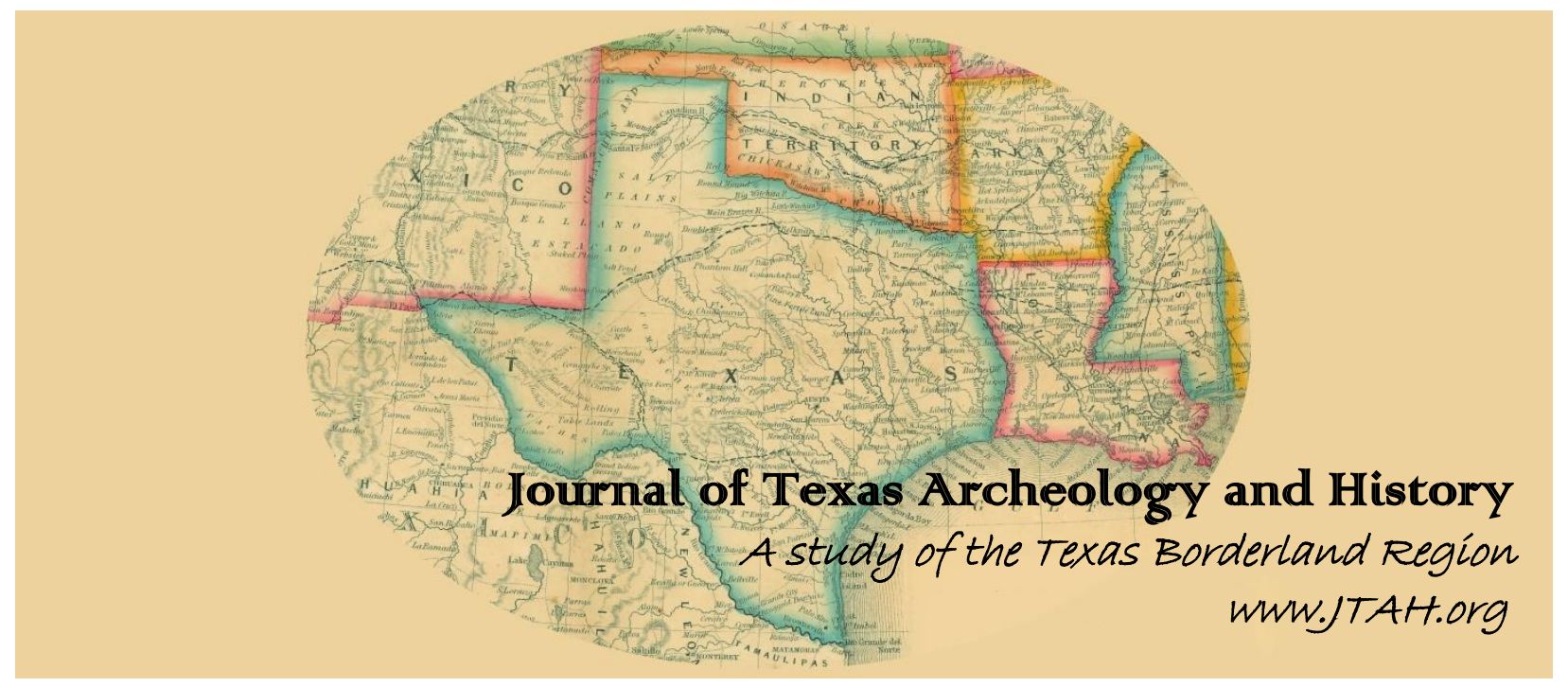

\section{Article Title: AN UNUSUAL LATE ABORIGINAL ASSEMBLAGE FROM THE WILSON SITE (41SS186), SAN SABA COUNTY, CENTRAL TEXAS}

\section{Author(s): $\quad$ Charles A. Hixson with a contribution by James K. Feathers}

Original Source: J.T.A.H. Volume 3 (2016/2017), Article 2, pp. 37 - 82; online 09 June 2016

Recommended Citation: Hixson, Charles A., and James K. Feathers; "An Unusual Late Aboriginal Assemblage from the Wilson Site (41SS186), San Saba County, Central Texas", (2017), Journal of Texas Archeology and History Volume 3 (2016/2017), pp. 37 - 82.

Copyright $(2017$ by Journal of Texas Archeology and History.org, Inc. All rights reserved. Online/Digital publication: ISSN 2334-1874

The online, digital, and print versions of the publication "Journal of Texas Archeology and History" are published by Journal of Texas Archeology and History.org, Inc., a Texas nonprofit IRC Section 501(c)(3) corporation.

Reproduction, posting, transmission, or other distribution or use of the Journal volume, individual article or any portion of the material therein, in any medium, is permitted strictly for personal, non-commercial purposes via a personal-use exemption under a Creative Commons license granted by JTAH.org, Inc. This license exemption requires, as a condition of its granted permission, proper credit be attributed to JTAH.org as copyright holder (e.g., Journal of Texas Archeology and History.org (c) 2017). No part of this publication may be reproduced, posted, transmitted, or otherwise utilized or distributed in any form by any means or method for commercial purposes without the express written consent of the Publisher. Inquiries should be addressed to JTAH Publisher, Suite 307, Box 361, 5114 Balcones Woods Drive, Austin, Texas, 78759.

The Journal of Texas Archeology and History.org is an organization dedicated to furthering research, education and public outreach in the fields of archeology and history concerning Texas and its bordering states of Louisiana, Arkansas, Oklahoma, New Mexico and Northern Mexico; a region we call the "Texas Borderlands." The J.T.A.H. is collaborating with the Index of Texas Archaeology and S.F.A.S.U. to distribute their publication library to the general public via free and open-access channels. Visit www.JTAH.org to submit an article. 


\title{
AN UNUSUAL LATE ABORIGINAL ASSEMBLAGE FROM THE WILSON SITE (41SS186), SAN SABA COUNTY, CENTRAL TEXAS
}

\author{
Charles A. Hixson \\ with a contribution by James $K$. Feathers
}

\begin{abstract}
The late aboriginal component in the Wilson Site in San Saba County is unusual in that most of the assemblage is consistent with that of Classic Toyah, but the diagnostic projectile point is an unnotched triangular arrow point instead of the typical Perdiz point. The absence of Perdiz points suggests that this component is associated with non-Toyah people and possibly dates to after 1700. Archaeological testing by the Llano Uplift Archeological Society (LUAS) to find supporting evidence for a historic date identified an Austin phase shell midden and a "Late Component" composed of triangular arrow points, end scrapers, a beveled biface and bone-tempered sherds, but no items of European manufacture. Complicating matters, the luminescence dating on a ceramic sample opens the possibility that the Late Component predates the currently accepted beginning of the Toyah phase.
\end{abstract}

Keywords: Toyah, Guerrero, Fresno, Perdiz, Harrell, Apache, Jumano, luminescence

\section{INTRODUCTION}

The Perdiz point is the most common diagnostic arrow point of the Late Prehistoric II and early historic Toyah phenomenon of central and south Texas. It is the "key element" of the Toyah toolkit (Turner et al. 2011:194), which also includes beveled bifaces, flake drills, large end scrapers, and bonetempered ceramics (Prewitt 1981:83). While other arrow point forms occur in many Classic Toyah components, Perdiz is the predominant arrow point type (Kenmotsu and Boyd 2012:10) and the one arrow point style that is "distinctively" Toyah (Carpenter 2012:183). The Wilson site (41SS186), located on the lower San Saba River well within Johnson's (1994:Figure 106) Classic Toyah area, is unusual in that it contains a late aboriginal component with an assemblage nearly indistinguishable from Toyah, with all the diagnostics noted above, but no Perdiz points.

The only arrow points that have been recovered from the Late Component are thin, well-made triangular forms without stems or notches. Similar arrow points have been reported in other Toyah components, but they are usually far outnumbered by Perdiz points. For example at 41TG91, a

\footnotetext{
JOURNAL OF TEXAS ARCHEOLOGY AND HISTORY

VOLUME 3:37-82

THE ONLINE PUbLICATION JOURNAL OF TEXAS ARCHEOLOGY AND HISTORY (ISSN 2334-1874)

IS PUBLISHED BY JOURNAL OF TEXAS ARCHEOLOGY AND HISTORY.ORG.

COPYRIGHT (C) 2016 JOURNAL OF TEXAS ARCHEOLOGY AND HISTORY.ORG. ALL RIGHTS RESERVED.
} 
Classic Toyah component with an unusually large number of triangular points, 34 Perdiz points were found compared to nine triangular forms (Creel 1990:90, 96). More typical is the Varga site, where 53 Perdiz points were recovered compared to two triangular arrow points (Quigg et al. 2008:238, 243). Only at 41LL473, another site that will be described in this report, are the number of Perdiz and triangular points even comparable, but this site has been minimally investigated with one example of each point type recovered. Wilson is unusual for a well-investigated Late Prehistoric II/early historic component on the Edwards Plateau in that all the recovered arrow points are triangular points.

Recent models of the Toyah phenomenon have attempted to explain the apparent homogeneity of Toyah material culture and its seemingly rapid spread across the Edwards Plateau, South Texas, and parts of adjacent regions. These models include Toyah as a "techno-complex" or specialized toolkit for hunting and processing large game animals that diffused through existing groups (Ricklis 1994:301-304), as the in-migration of extra-regional people (Johnson 1994:271-281), as a social field or risk-sharing network (Arnn 2012:35, 235-236), and as long-range logistical hunters from outside the Classic Toyah area (Carpenter 2012:244-245). Johnson's migration model includes the concept of a "Classic Toyah area" where Late Prehistoric II components are expected to have the typical Toyah toolkit mentioned in the opening paragraph, especially Perdiz points and bone-tempered ceramics. Johnson posited that the Classic Toyah represented a single social group ("ethnic group") that had migrated into the area perhaps from the Mogollon region to the west. The "Classic Toyah" concept has continued to be used by Toyah researchers although most would now argue for a more diverse and dynamic social situation within this area (Kenmotsu and Arnn 2012:41), which probably contained multiple linguistic/marriage groups (as used by Arnn 2012:34), based on the large number of naciones documented by Spanish sources for the early historic period (Arnn 2012:113-116, 134-135; Kenmotsu and Arnn 2012:26-27; Wade 2003:222).

The available archaeological evidence suggests that most if not all of the groups that resided in the Classic Toyah area during the Late Prehistoric II and early historic period used Perdiz points to tip their arrows. Other arrow point forms, including triangular points, are generally considered to have originated from outside this area. For example, Arnn (2012:226) sees the large percentage of nonPerdiz points at 41TG91 as indicative of the permeable boundary between Classic Toyah groups and those to the north where triangular and side-notched points are common in Late Prehistoric II components. It should be pointed out that 41TG91 and most large Toyah sites that include non-Perdiz points are most likely palimpsests with multiple Toyah occupations. Arnn (2012:225) considers this site and other similarly large ones as residential base camps representing multiple occupations of "community/band size" groups ("minimal bands" as defined by Kelly 1995:210-213). At such sites individual social units are not easily discerned and there is no way to know how these "foreign" points entered Toyah residential sites. Wilson is different in that the Late Component represents a specialized site where a small-scale social unit, perhaps a family group or a few individuals engaged in a short-term activity, possibly bison hide preparation as suggested by the high percentage of end scrapers. There is also evidence that triangular arrow points were being manufactured at the site, so these hunters not only used these triangular points but were the makers as well. 
The Wilson site is located in a part of central Texas without large-scale excavations of Toyah components, although one large Classic Toyah site $20 \mathrm{~km}$ to the northwest is known from surface collections (Green and Hester 1973), and Toyah components have been investigated at two sites immediately opposite the San Saba River from Wilson (Hixson et al. 2011; Prikryl et al. 2010). Perdiz points are dominant in all these components with only small percentages (if any) of non-Perdiz points. None of these Toyah components have been radiocarbon dated so a chronological separation between them and Wilson is possible.

But if these components are more or less contemporaneous, then Wilson's Late Component could involve a small-scale social unit or even an individual who happen to use a style of arrow point different others in their linguistic/marriage band. Their proximity to the Southern Plains would mean they were routinely exposed to triangular arrow points through contact with groups to the north. The use of triangular points could be an example of assertive style as formulated by Wiessner (1983:258259), where style is used to signal individuality without reference to any group membership. Assertive style can have a random or clinal distribution (Wiessner 1983:259), which is the pattern we see with these northern triangular points in Toyah lands.

Alternatively, these triangular arrow points could have been used by all hunters in a larger social unit, such as a marriage/linguistic group, with the Late Component representing only a subgroup. Such a large-scale group should be highly visible archaeologically because of its geographical and population size, but sites with a predominance of triangular arrow points have not been reported in this part of central Texas, or for that matter elsewhere in the Classic Toyah area. While this might be due to small sample size, such a group might not have existed long enough to leave much of a record, as would be the case for migrating peoples.

Whether newcomers or not, a large social unit could have used triangular points to communicate their social identity and to maintain a social boundary between themselves and other groups in the area (Wobst 1977:320-330). Wiessner's (1983) ethnographic work on Kalahari San arrow points shows that (metal) arrow point styles can carry social information, and in this particular study, signal membership in large, risk-sharing social units (language groups). Wiessner (1983:257-258) used the term emblemic style for formal variation in material culture that purposefully carries social information on group identity, in contrast to her assertive style, which carries messages of individuality. She also felt that both types of stylistic information could be carried by stone projectile points as well, so should be applicable to many archaeological contexts where large game hunting was culturally important, as was presumably the case with Toyah and Southern Plains societies. Weissner's main critic has been Sackett (1985, 1990:38-39) who argues that emblemic-type style ("iconological style") is rare and that most variation in material culture does not actively carry social messages but instead results from "isochrestic" choices, where particular ways of making an artifact are chosen from functionallyequivalent options. Such choices can become ensconced in a social group and therefore will result in an "ethnic style." Whether purposefully carrying social messages or made out of habit, Perdiz points and the Wilson arrow points were most likely produced by different peoples.

Following Wiessner's emblemic style, Arnn (2012:140, 203-206) argues that the Perdiz point was used as a marker for participation in a large social field that spanned most of the state and connected 
many different groups and communities in the Late Prehistoric II and early historic periods. Drawing on the work of Lesser (1961) and McBrinn (2005), Arnn put forth the idea that Toyah is a risk- and information-sharing network composed of numerous cultural/linguistic groups in central, south, and east Texas. In his view, Toyah is not an ethnic group or specific people, nor is it a techno-complex, although this network did facilitate the spread of ideas and technologies. This social field was known in the early historic period as the Tejas Alliance, but Arnn (2012:136-139) presents evidence that it had prehistoric beginnings.

If Arnn is correct about the emblemic use of the Perdiz point, then the Wilson site occupants may not have been members of the Tejas Alliance, or the site could date to the period after 1700 when this social field had collapsed and a new marker of shared identity, the Guerrero point, came into widespread use among aboriginal people living in south Texas Spanish missions (Arnn 2012:140-142). The Wilson site triangular points do resemble Guerrero points because of their shape and fine oblique pressure flaking (Turner et al. 2011:194), but it's unlikely the Late Component represents missionized people because of the distance $(300 \mathrm{~km})$ from the nearest missions in San Antonio. The Wilson site is geographically much closer to a short-lived mission and Presidio $100 \mathrm{~km}$ upstream on the San Saba River, the latter possibly housing some missionized Native Americans because two Guerrero points were recovered during excavations (Walter 2004:103-104). However, the presidio was under virtual siege by hostile norteño groups throughout its existence and these people probably wouldn't dare venture to hunt so far from the fort.

The Wilson site Late Component could possibly be a post-1700 aboriginal site occupied by former members of the Tejas Alliance outside the area of Spanish settlement. It could show that the basic Toyah toolkit persisted in at least one non-mission group on the northern Edwards Plateau after the demise of the Perdiz point. Alternatively, Wilson could represent people who never were part of the Tejas Alliance, and therefore the Late Component could date to anytime in the Late Prehistoric II or early historic periods. Possibly, it was sometime during the seventeenth and eighteenth centuries when Southern Plains groups, whose hunters used triangular arrow points, were migrating southwards into central Texas (Newcomb 1993; Wade 2003:160-215).

\section{Environmental and Archaeological Setting}

The Wilson site is located on the northern edge of the Edwards Plateau in the broad alluvial valley of the San Saba River (Figure 1) with the Cross Timbers immediately to the north, the Limestone Plains to the northwest, and the Limestone Cut Plain to the northeast (Griffith et al. 2007). The site occupies a high terrace $300 \mathrm{~m}$ north of the river near the town of San Saba. The geology of this high terrace is mapped as Pleistocene terrace, while the low-lying area from the terrace slope southwards to the river is mapped as Holocene alluvium (Barnes 1976). The Wilson cultural material extends from the high terrace edge northwards across the Pleistocene surface for a distance of about 200 meters. This area includes a main house, a guesthouse, animal pens, and a paved road; buildings and roads cover roughly 12 percent of the site area. The house was built in 1913 (landowner, personal communication), and most of the Wilson site area has probably been under cultivation for over century. 


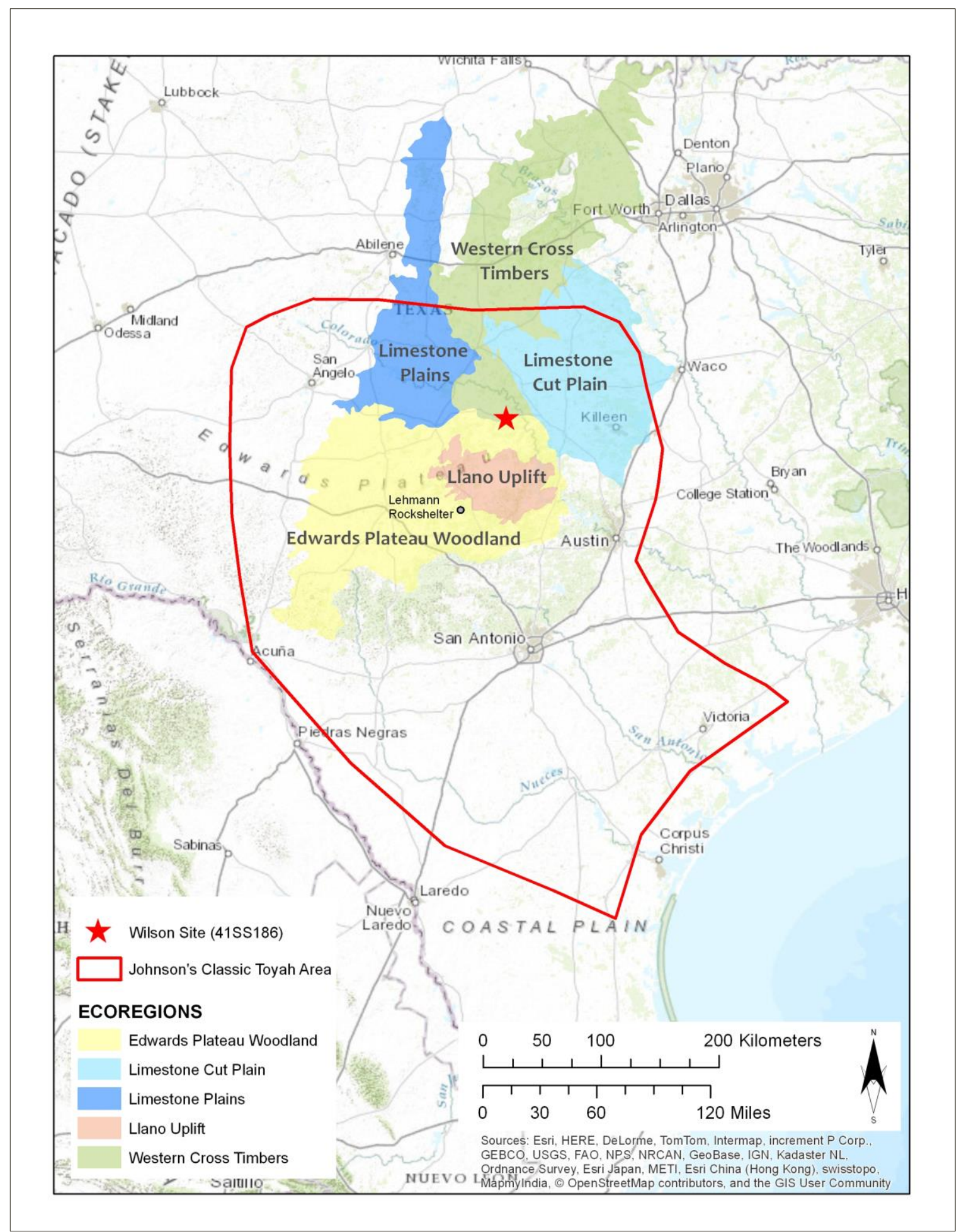

Figure 1. Map showing the central Texas region with ecoregions in the vicinity of the Wilson site, Ecoregions are from Griffith et al. 2007.

As would be expected in this geological setting, Wilson is essentially a surface site but with considerable cultural material shallowly buried in the plowzone. It contains two recognizable components in the sense of archeological cultures: an early Late Prehistoric (Austin phase) 
component with Scallorn and Sabinal-like arrow points that appears to cover the entire site area but is mainly concentrated in a mussel shell midden at the south end of the site; and a late aboriginal component with triangular arrow points and ceramics occupying a discrete area in the northern part of the site away from the terrace edge. Obviously, the late component completely overlaps and is presumably mixed with the earlier one, although where the earlier cultural material appears sparse.

Charcoal from the shell midden was sent to Beta Analytic for radiocarbon dating to determine when the Austin phase occupation took place, and if there is any conceivable relationship between this component and the later component. Although it would seem a bit far-fetched, a very late Austin phase occupation could overlap early Toyah and possibly mean that the two groups were camping together. Such a scenario could explain the proximity of two occupations in an area where water is not immediately available. However, the dating of the Austin component turned out to be early, with the calibrated result being (95\% probability) Cal AD 655 to 720 and Cal AD 740 to 765 (Beta-415724, using INTCAL database [Reimer et al. 2013] and "A simplified Approach to Calibrating C14 Dates" [Talma and Vogel 1993]). These periods place the Austin component to essentially the very beginnings of the Late Prehistoric in central Texas, and even taking into account the "old wood" problem (Schiffer 1986), well before any Toyah occupation, especially one that could be very late.

While the Austin phase component is interesting in its own right because of its early date and because it contains a largely intact shell midden, this report will focus on what is here called the Late Component with its unusual artifact assemblage related to Toyah and possibly dating to the early historic period. The investigations reported here were carried out by volunteers from the Llano Uplift Archeological Society (LUAS) in an attempt to find supporting evidence for the post-1700 dating. It includes both fieldwork and subsequent analysis of the finds, as well as the results of the University of Washington's thermoluminescence dating of a sample of the ceramic material. A literature review was also undertaken to look at the co-occurrence of Perdiz and unnotched triangular arrow points to better place the Wilson site in a broader regional perspective.

\section{BACKGROUND TO THE INVESTIGATIONS}

Buddy Whitley, the Texas Archeological Stewardship Network (TASN) Steward for San Saba County, first visited the site early in October 2012 at the invitation of the landowner, and noted mussel shell and chert flakes in the garden area near the high terrace edge. He contacted me a few days later to request assistance from LUAS in surveying the property for archaeological sites, which was arranged for the following month. The LUAS volunteers walked over the floodplain but saw no artifacts on the surface. This floodplain, or low terrace, appears to lie at the same elevation as the terrace on the opposite side of the river, which had earlier been intensively shovel-tested for a park development project (Prikryl et al. 2010). The shovel testing in the park recovered no cultural material, which suggests that the sediments in the upper meter of the formation are too young to contain intact prehistoric cultural material.

Aware of this situation, the LUAS volunteers concentrated their efforts on the surface of the high terrace where they excavated eight shovel tests close to the terrace edge. One of the tests encountered 
dense mussel shell and debitage near the surface in the garden area by the house, while the other tests had fairly light recovery, generally a few pieces of debitage or less. Near the end of the day, a few Toyah artifacts were noted on the surface in an animal pen north of the house. These artifacts included three bone-tempered ceramic sherds and an end scraper, as well as an unnotched triangular arrow point. The locations of these finds were recorded with a GPS ( $\pm 3 \mathrm{~m}$ accuracy), and with landowner's permission, the point, scraper, and ceramics were collected for further analysis, which was postponed for over a year.

My interest in the Wilson site and its research possibilities was rekindled after reading the report on testing and data recovery from the Flatrock Road Site, 41KM69, in Kimble County that was done by the Center for Archaeological Research (CAR) for the Texas Department of Transportation (Thompson et al. 2012). The site is located about $161 \mathrm{~km}$ (100 miles) southwest of Wilson, and contains Late Archaic and Late Prehistoric components buried in terraces on the South Llano River. Of interest here is the latest aboriginal component on the lower terrace that possibly represents a historic Toyah occupation (Thompson 2012:105-107). The excavations recovered bone-tempered ceramics from this component, as well as Toyah-style end scrapers but no arrow points. The CAR archaeologists submitted portions of the same six ceramic sherds to two dating laboratories, one set for luminescence dating, the other for AMS radiocarbon dating. Four of the six luminescence dates were historic in age and ranged from $\mathrm{AD} 1526 \pm 38$ to $\mathrm{AD} 1749 \pm 43$, while the AMS results on the same samples were significantly earlier, ranging from AD 994-1023 to AD 1224-1263 (Thompson 2012:Table 10-1). The luminescence dates appear to be more accurate for the component than the AMS dates, considering the stratigraphic position of the samples above an earlier Toyah component. It is possible that the discrepancy between the two dating methods was caused by "old wood" used in firing the ceramics (Thompson 2012:107), because luminescence dates the time when the pot was fired, while AMS dates the time when the wood used as fuel, either for firing the pot or for cooking, was actively growing. These two events could be centuries apart, although it would seem unlikely that Toyah people would be using 300-year-old wood - in such a case, it would have to be heartwood - to fire their pots. It should be pointed out that AMS is dating all the organic material in the sample, including whatever was being cooked and organic material absolved from the soil. Interestingly, AMS dating of Toyah sherds from the Varga site, Buckhollow, Mission San Lorenzo, and Mission San Juan (San Antonio) also resulted in a high percentage of dates that were clearly too old (Quigg et al. 2008:280, 281).

Not only do CAR's findings suggest that post-1700 Toyah-affiliated sites might exist in the region, but that luminescence dating can offer better results for historically late sites than AMS, at least when dating ceramic material. Luminescence also offers the best dating method for open sites like Wilson's Late Component that are confined to the surface or plowzone and lack organic materials that can be radiocarbon dated (Feathers 2003:1500). Because luminescence dating could provide further evidence for the post-1700 age of the Late Component, LUAS submitted a ceramic sample to the same lab that CAR used, the University of Washington's Luminescence Laboratory, which specializes in the dating of archaeological samples. Before the sample was sent, LUAS made a return visit to the Wilson site to collect a soil sample needed by the lab to measure background radiation. 


\section{INVESTIGATIONS}

While collecting the soil sample, we happen to find more ceramic sherds and other surface Toyah artifacts in addition to another triangular arrow point. It was then decided that a thorough investigation of the site was necessary to address the follow questions:

1. What are the areal extent and density of the late cultural material (what would be called the Late Component)?

2. Are European artifacts associated with the Toyah diagnostics?

3. Are Perdiz or other arrow point types present, in addition to the triangular points?

4. What is the connection, if any, of the Late Component to the dense shell accumulation at the south end of the site?

Considering the shallow cultural deposits, all these questions could be addressed using intensive surface inspection and shallow subsurface testing of the plowzone. The investigations were carried out by LUAS volunteers in the fall and winter of 2014/15, during which more shovel tests were dug for a total of 25 tests, along with seven 1-x-1-m test units excavated by trowel and skimming with a shovel (Figure 2). The earlier shovel testing had shown that the cultural deposits on the high terrace surface are shallow and confined to the plowzone, mostly in the upper $20 \mathrm{~cm}$. The soil profile to a depth of a meter is brown clay loam with no clear soil horizons although small calcium carbonate nodules are present below $30 \mathrm{~cm}$. Chert gravels outcrop on the terrace edge and slope, as well as the terrace surface in the northwest corner of the property. These areas, along with the recently plowed area north of the animal pen visible in Figure 2 were not shovel tested because of the excellent visibility. Elsewhere the subsurface testing was done to collect a sample of the plowzone cultural material and not necessarily to explore for buried features or discrete occupation zones, which if they had existed would have been dispersed by plowing.

To address Question 1 above, a careful inspection was made of the terrace slope and terrace surface areas of the Wilson property and the adjoining properties to the north and northwest, encompassing 6.3 acres in all. Ground visibility was good within the pen areas because of superficial erosion from animal traffic. In addition, a series of 14 shovel tests were placed at roughly $20-\mathrm{m}$ intervals across this area to determine artifact extent and density within the plowzone (upper $30 \mathrm{~cm}$ ).

To address Questions 2 and 3, five 1-x-1-m test units were placed within the area where Late Component diagnostics were found during the surface survey. The purpose of the tests was to recover any items of European manufacture datable to the seventeenth or eighteenth century. Many aboriginal groups in Texas had access to European trade goods through information networks tied to trade and trade fairs (Wade 2003:228). Considering the value that must have been placed on such items by aboriginal people, it's unlikely that they were casually discarded to become part of the archaeological record of small specialized sites such as Wilson. Still, a few large aboriginal sites with European 


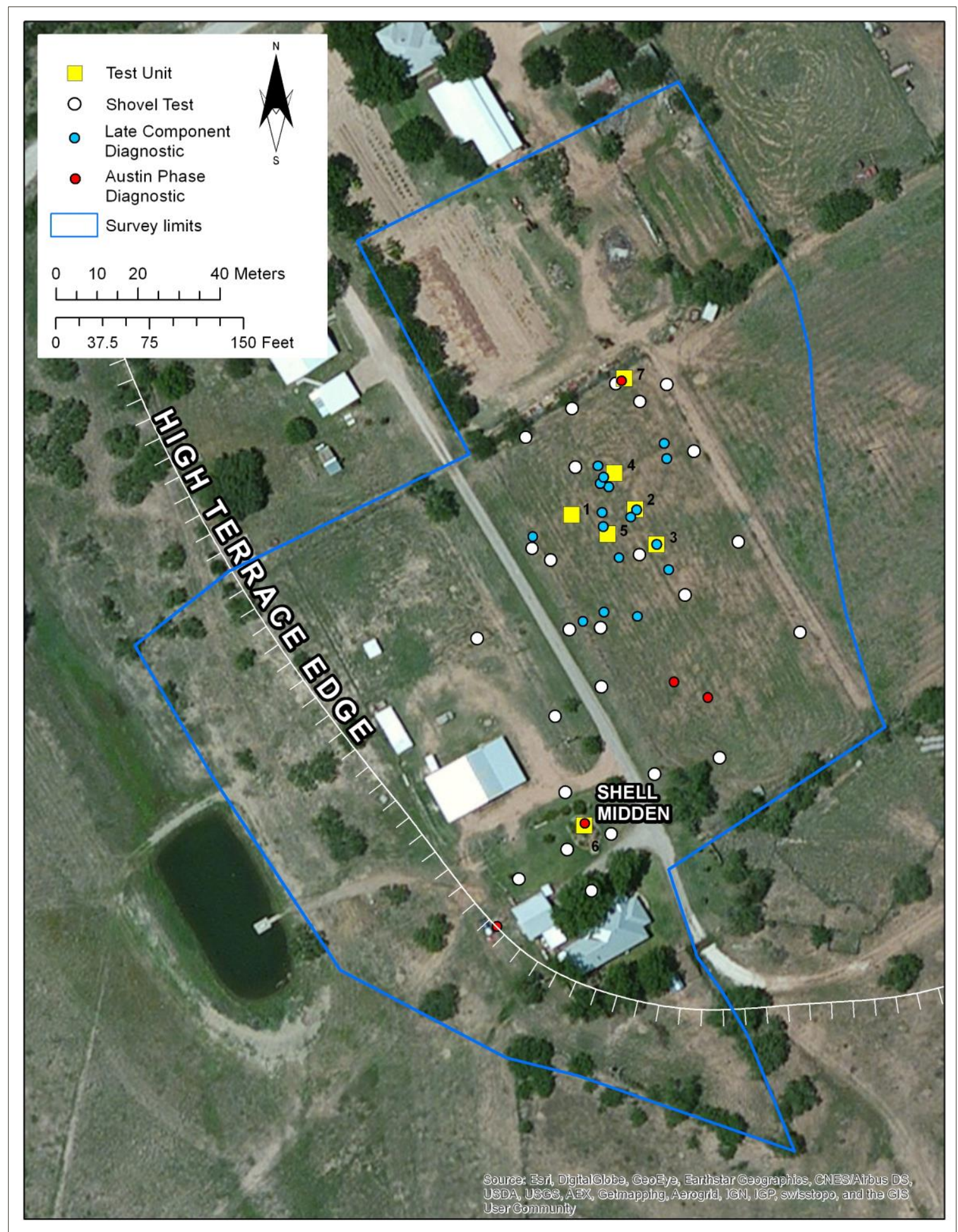

Figure 2. Aerial map showing subsurface testing done by LUAS volunteers, and limits of surface survey (blue line).

artifacts have been documented just outside the Classic Toyah area, including the Davis Hackberry Spring site (41ST87) with glass beads and a metal arrow point (Riemenschneider 1996:17), and the Shanklin site (41WH8), with a Spanish coin, an iron projectile point, and tools made from chipped bottle glass (Hudgins 1986). 
The original plan was to fine screen all of the fill from all the units in the Late Component area to recover possible glass beads or other small artifacts, but that proved extremely difficult because of the hard soil. Instead, one 10-cm level of Unit 1 was $1 / 16$-inch screened and the entire fill of Units 2 and 3 were $1 / 8$-inch screened, while a sample of Unit 5 fill was also $1 / 8$-inch screened. The fine screening was done in addition to the $1 / 4$-inch screening that was done on all fill from all units and shovel tests during the investigations. A metal detector was briefly used in the Late Component area to locate metal artifacts, but was soon stopped because of the large number of hits resulting from fence staples, wire, and small metal fragments presumed to be modern. Another 1-x-1-m test unit was placed $20 \mathrm{~m}$ to the north of the Late Component on the property fence line where a previous shovel test had recovered somewhat more debitage than elsewhere in the animal pen.

To help address Question 4, a 1-x-1-m test unit was placed within the area where earlier shovel testing encountered dense mussel shell and lithics. Additional shovel testing was done immediately to the north to determine the extent of the shell midden.

\section{TESTING RESULTS}

The investigations found that all the Toyah artifacts are confined within a discrete $1,431-\mathrm{m}^{2}$ ( 0.35 acre) area at the north end of the main animal pen (Figures 3 and 4). I consider this the Late Component area, and assume that all these Toyah artifacts are the product of a single occupation or a series of occupations by the same social unit over a narrow time spam. This assumption is based on the tight horizontal clustering of artifacts that seem to belong together in a location that appears to be unfavorable for repeated occupations because of the absence of water and other obvious resources. It is not based on stratigraphic separation because the artifacts were retrieved from the disturbed plowzone, and there is always the possibility that they did indeed accumulate from multiple Toyah occupations over a longer span of time.

Most of these Toyah diagnostics were recovered from the surface, but two, a triangular point and an end scraper, were recovered from separate test units. No Perdiz points were recovered, and no items of non-aboriginal manufacture were found other than a few pieces of purple glass, whiteware sherds, and small, unidentifiable corroded metal fragments, all of which probably date from the early twentieth century. Also, no lithic tools resembling gunflints were found. Shovel testing showed that the $1 / 4$-inch debitage density within the Late Component area was about the same as in the rest of the animal pen, averaging about 3 pieces per test (see Figure 3).

Outside the Late Component area, LUAS recovered four stemmed arrow points. These include an unfinished Scallorn point and a Sabinal-like point from the surface to the south of the Late Component area and a probable Scallorn point from the test unit placed on the north fence line. A third Scallorn point was recovered from the test unit over the shell midden in the southern part of the property (see Figure 2). 


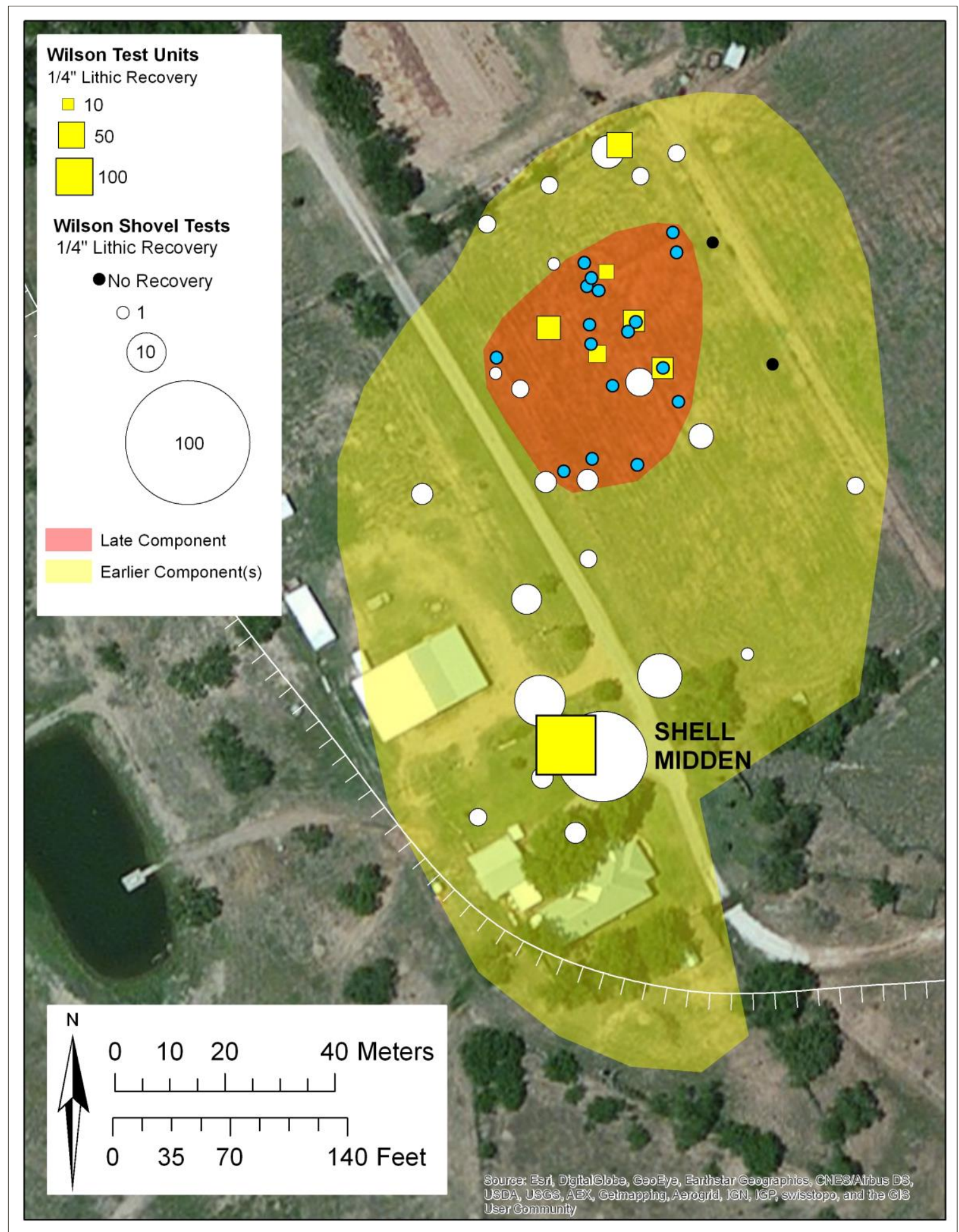

Figure 3. Aerial map showing the $1 / 4$-inch debitage recovery (upper $20 \mathrm{~cm}$ ) from the shovel test and test units using graduated symbols, with Late Component area shaded in red. 


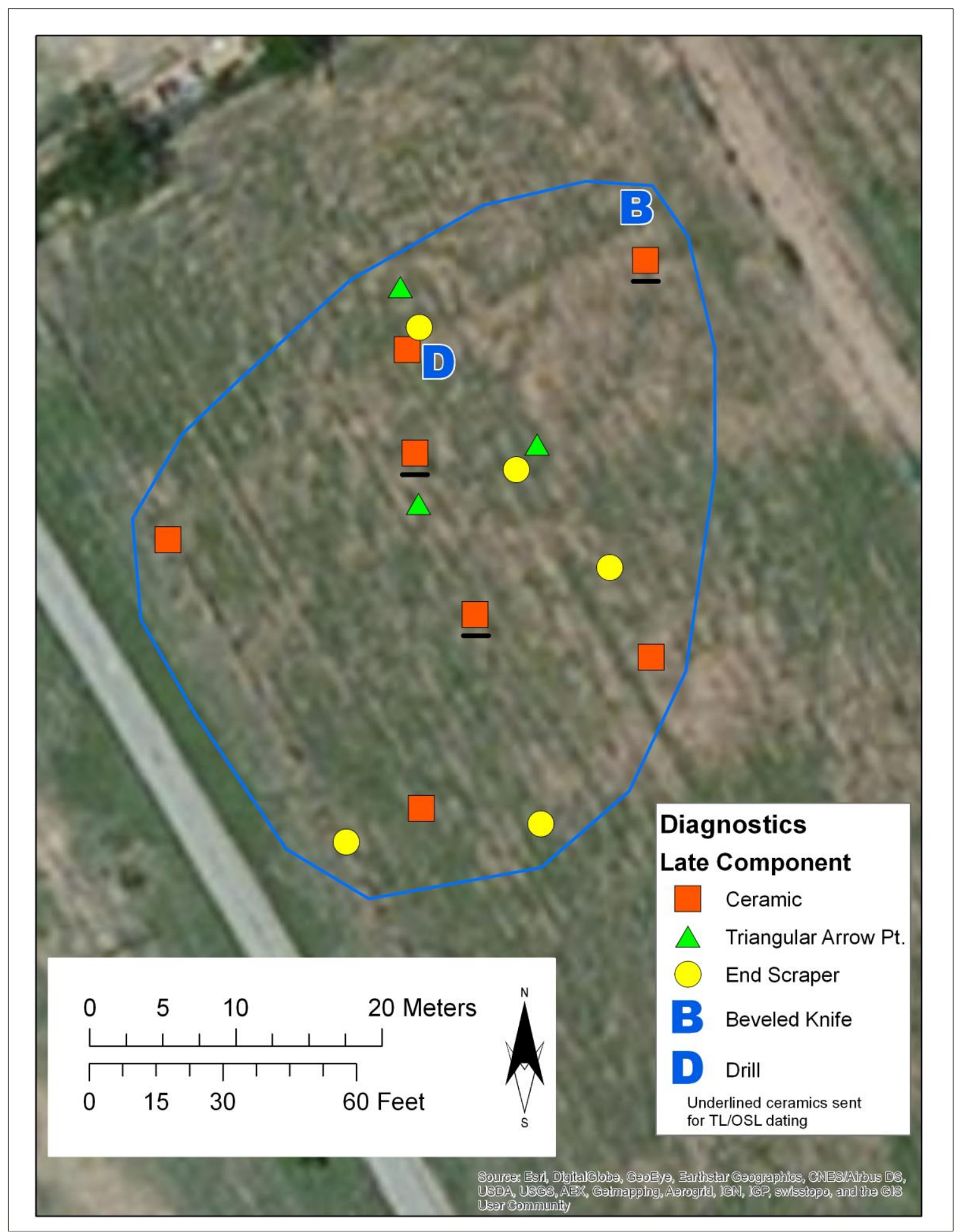

Figure 4. Aerial of Late Component area showing locations of Toyah artifacts and triangular arrow points.

The unit placed in the shell midden area near the house encountered a dense mussel shell lens comingled with many small burned limestone rocks and lithics. The lens is $10 \mathrm{~cm}$ thick and lies between 10 and $20 \mathrm{~cm}$ below the surface. The only diagnostic artifact from the unit was a Scallorn point (mentioned above) recovered from the upper part of the shell lens. A thin late-stage arrow point 
preform with a concave base was also recovered from the same elevation as the arrow point. No Toyah artifacts or triangular points were found in this unit. As stated in the Introduction, a calibrated radiocarbon date (95\% probability) of Cal AD 655 to 720 and Cal AD 740 to 765 was obtained on charcoal from the upper part of the shell lens (Beta-415724). Shovel testing near this unit shows that the shell lens or midden gradually thins towards the north and east and probably covers an area of 400-600 $\mathrm{m}^{2}$ (see Figure 3).

\section{Temporally Diagnostic Artifacts considered belonging to the Late Component}

These artifacts were all recovered from the $1431 \mathrm{~m}^{2}$ Late Component area in the northern part of the animal pen, and with the exception of the triangular arrow points, are artifact forms archaeologists typically identify as Toyah phase when found within Johnson's Classic Toyah area. No artifacts diagnostic of other archaeological cultures were found in the Late Component area. However, some non-diagnostic tools and unfinished tools were collected from this area and these are described in the next section.

\section{Unnotched Triangular Arrow Points $N=3$ (Figure 5)}

Lot 1 represents the proximal fragment of a triangular arrow point missing its roughly distal third, which was broken off in an oblique snap fracture, as well as one of its basal corners. The point is bifacially worked with a somewhat plano-convex cross-section. In workmanship, it shows neat, oblique parallel pressure flake scars on both faces. The edge margins are even with no serrations. The base is moderately concave, with a maximum depth of $2 \mathrm{~mm}$. The point is widest at its proximal end, which measures $17 \mathrm{~mm}$ across, and if its basal corner were intact, might have measured $18 \mathrm{~mm}$. The existing part of this point has a maximum length of $26 \mathrm{~mm}$. Its thickness is fairly uniform throughout its length at $2.5 \mathrm{~mm}$. The specimen is made of slightly translucent brown Edwards chert with cream inclusions of similar texture. This artifact was found on the surface.

Lot 7 represents the proximal fragment (perhaps proximal third) of a small triangular arrow point. The distal part has broken off through a straight bend fracture. It is nearly paper-thin, with a uniform thickness of 1.5 $\mathrm{mm}$, and appears plano-convex in crosssection. The point is essentially unifacial with one side showing only minimal pressure flaking with short, minute flake scars all along the lateral edges and the base but leaving most of the interior flake blank surface intact. Compression rings on this surface indicate

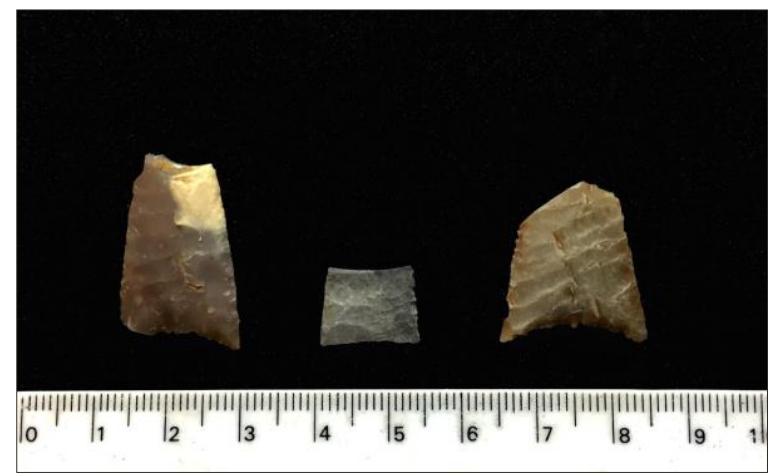

Figure 5.Unnotched triangular arrow points recovered from Late Component, 41SS186. (left to right) Lot 1, Lot 7, and Lot 24. that the point's distal tip lay at the proximal end of the original flake blank. Although the fragment is small, the opposite face shows three rows of fine horizontal parallel flaking. It has a slightly concave base less than $1 \mathrm{~mm}$ deep. The maximum width at the base is $14.5 \mathrm{~mm}$ and the length of the surviving 
part is $10.5 \mathrm{~mm}$. It is made of a fine-textured opaque chert in lightly mottled shades of gray. This point was found on the surface.

Lot 24 represents the distal half of fairly wide but thin triangular arrow point. One face still shows the interior side of the original flake blank with short trimming flakes removed along its lateral edges and longer flakes along the basal edge. The other face shows the fine type of oblique parallel pressure flaking seen on the Lot 1 specimen. As with the other two arrow points, the widest point it as its base, which measures $21 \mathrm{~mm}$. The surviving part measures $22 \mathrm{~mm}$ in length, and is uniform in thickness at $2.5 \mathrm{~mm}$. The point is made from translucent brown Edwards-type chert. This point was recovered from Level $2(10-20 \mathrm{~cm})$ in Test Pit 2.

\section{Flake Drill N=1 (Figure 6)}

This tool fragment represents the medial section of a flake drill, including a substantial part of the bit along with a section of the tool immediately above the bit. The surviving part of the bit is $13 \mathrm{~mm}$ long, $6 \mathrm{~mm}$ wide, and 4 $\mathrm{mm}$ thick. The surviving proximal part is too small to say much except that this tool probably isn't a recycled arrow point. The drill is made from a fine-textured opaque white chert.

\section{Beveled Biface $N=1$ (see Figure 6)}

This is an end fragment of biface whose lateral edges are alternately beveled. It is made

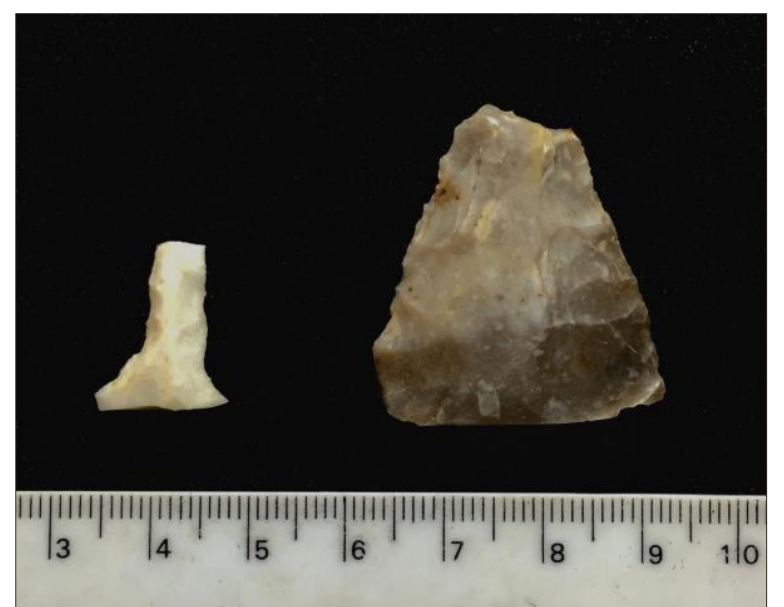

Figure 6. Lot 10 flake drill (left) and Lot 43 beveled biface fragment collected from Late Component, 41SS186. fine-textured medium gray chert with light gray mottling with no visible patina. The fragment measures $33 \mathrm{~mm}$ in length and $28 \mathrm{~mm}$ at its widest point. Similar bifaces are also referred to as "Harahey" knives (Johnson 1994:103).

\section{End Scrapers $N=6$ (Figure 7, Table 1)}

End scrapers represent the largest category of diagnostic lithic artifact found in the Late Component area, and are similar to ones found in Toyah assemblages such as Buckhollow (Johnson 1994:Figure 60C) but a little less carefully made than most. All are unifaces close in size and flaking technique, and were made from thick, hard hammer flakes. All but one of the scrapers have between 25 and 70 percent of their exterior surface covered by cortex. The scrapers range from 55 to $62 \mathrm{~mm}$ in length, and 41 to 51 in width. They vary from 15 to $24 \mathrm{~mm}$ in maximum thickness, with the thickest portion usually slightly proximal from the working edge. Using Johnson's (1994:Figure 65) terminology to describe the ventral surfaces at the bit, most are moderately to markedly curved with slight hooks, but two are flat. All are made from fine-textured, Edwards chert except for Lot 11, which is made of a black, coarse chert that might have originated in the San Saba area Paleozoic limestone. 
All these artifacts were surface finds except for Lot 31, which was recovered from Level $2(10-20 \mathrm{~cm})$ of Test Pit 3.

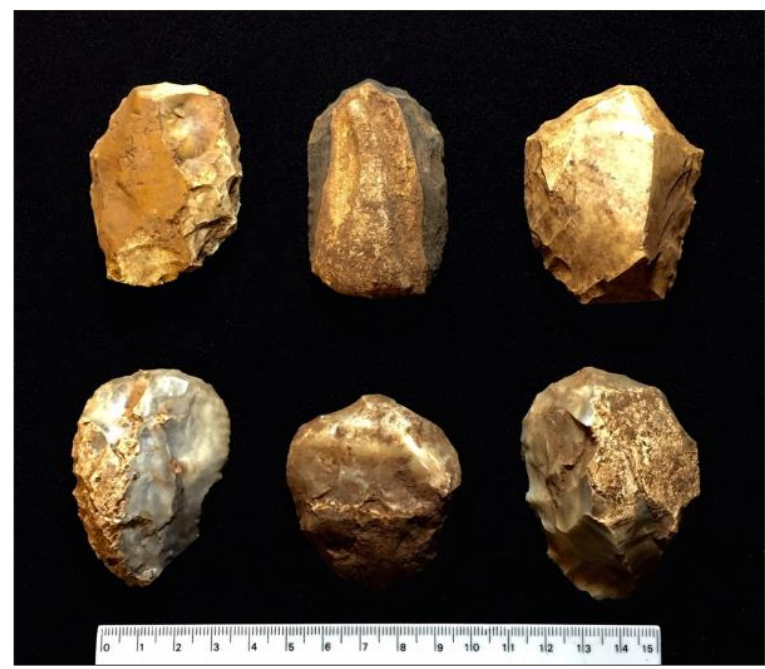

Figure 7. End scrapers recovered from Late Component, 41SS186. Upper row, left to right: Lot 4, Lot 11, Lot 12; Bottom row, Left to right: Lot 13, Lot 31, Lot 44

Table 1. Metric and nonmetric data for end scrapers from 41SS186.

\begin{tabular}{llllll}
\hline Lot & Length $(\mathrm{mm})$ & Width $(\mathrm{mm})$ & Thickness $(\mathrm{mm})$ & Ventral Surface $^{1}$ & Cortex $(\%)^{(\%)}$ \\
\hline 4 & 61 & 43 & 17 & Flat & 70 \\
11 & 62 & 41 & 16 & Moderately Curving & 60 \\
12 & 61 & 51 & 24 & Moderately Curving & 0 \\
13 & 59 & 41 & 16 & Moderately Curving & 25 \\
31 & 55 & 51 & 15 & Markedly Curving & 40 \\
44 & 62 & 46 & 24 & Flat & 40 \\
\hline Averages & 60 & 45.50 & 18.67 & & \\
\hline
\end{tabular}

${ }^{1}$ After Johnson 1994:Figure 65.

\section{Ceramics (bone-tempered sherds) $N=7$ (Figure 8)}

Seven small aboriginal bone-tempered sherds were collected from the surface, more or less scattered across the Late Component area without any apparent concentration (see Figure 4). None of the fragments could be fitted together. They represent body sherds from one or more vessels all having the same basic attributes and probably representing a constricted form such as an olla because their convex surfaces are more carefully smoothed and polished than their concave surfaces. Notably the exterior (convex surface) of one sherd is partially covered with a brown polished slip, but the other sherds could easily have come from the upslipped areas of the same vessel. No carbon deposits or food residue was visible on the surfaces. The condition of the sherds is generally good with slight surface erosion on two of the three sherds sent for luminescence dating. Their sizes range from the smallest at 10 by $11 \mathrm{~mm}$ to the largest at 20 by $26 \mathrm{~mm}$. Sherd thickness ranges from 4 to $6 \mathrm{~mm}$. 
The sherds' exterior (convex) surfaces are smooth with slight luster from polishing and the interiors of two of the sherds (Lots 82 and 83) are almost as smooth as their exteriors. The rest of the sherds have somewhat uneven concave surfaces, having slight valleys and troughs that are likely traces of coiling, but the high areas show some polishing as well. Small pits are frequent, especially on the interior surfaces and around some of the bone temper fragments, and might represent where the bone has dissolved or organic constituents have burned away. No inclusions such as sand were visible through a 10-x hand lens on any

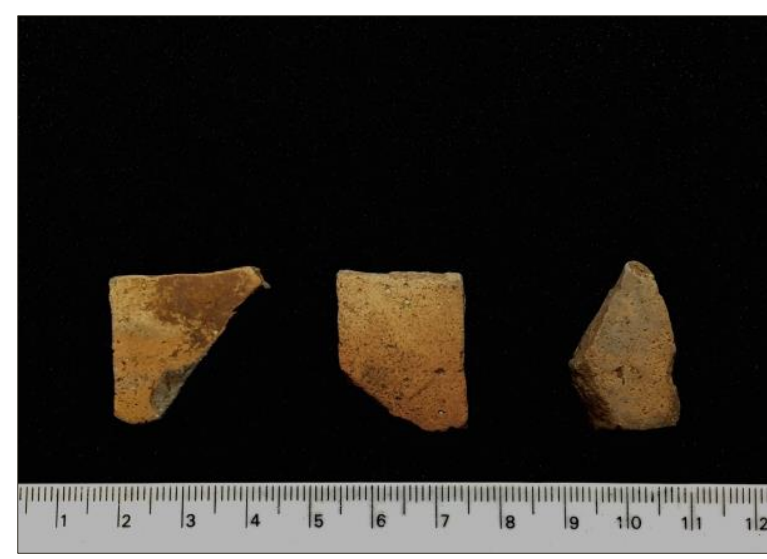

Figure 8. Three ceramic sherds collected from the surface of the Late Component area, 41SS186. The exterior (facing) side of the (Lot 3 ) sherd on the far left is particially covered by a brown polished slip. of the sherds other than moderate amounts of fine crushed bone.

Their exterior color is 5YR 6/6 (reddish yellow) for the more oxidized areas and 7.5YR 7/6 (reddish yellow) for the less oxidized areas. The interior surface has patches of oxidized areas with a color of 5YR 6/8 (reddish yellow) and reduced areas of 7.5YR 6/2 (pinkish gray). The core is reduced and is also $7.5 \mathrm{YR} 6 / 2$ (pinkish gray) with some oxidized areas close to the surface and some slightly darker areas of carbon staining. The slip on the exterior of the Lot 3 sherd is 7.5YR 4/6 (strong brown) and has a slight sheen from polishing. The slip is fairly thickly applied and stands in clear relief from the unslipped surface.

\section{Artifacts that might belong to the Late Component}

These artifacts were found in, or a short distance outside of, the Late Component area, but are not necessarily diagnostic to any particular period although the arrow point preforms are obviously Late Prehistoric. Their identity as possibly belonging to the Late Component rests in their proximity to the

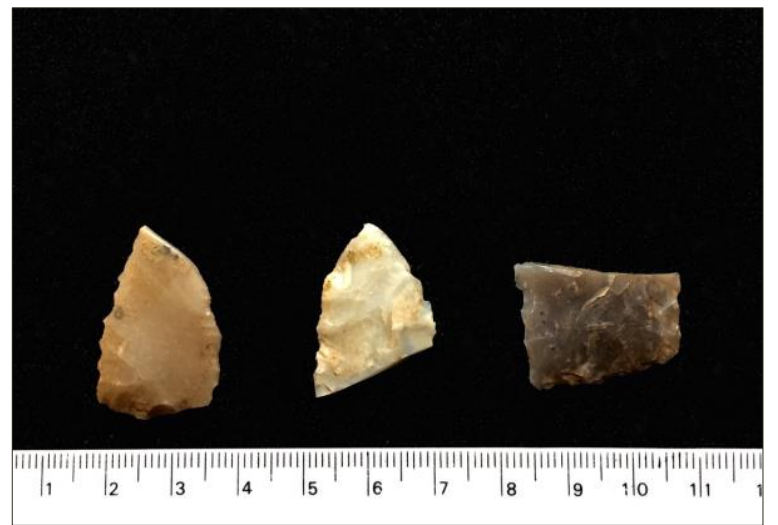

Figure 9. Arrow point blank (Lot 2 on left), and two fragments from arrow point preforms (Lot 8 middle and Lot 9, right) from the Late Component area, $41 \mathrm{SS} 186$. late artifacts, but they could belong to the Austin component or to earlier, unknown occupations.

\section{Arrow Point Preforms N=2 (Figure 9)}

Lot 8 represents the distal part of a biface whose thinness $(3 \mathrm{~mm})$ suggests that it is probably an unfinished arrow point. One side is only partially pressure-flaked with the original flake blank interior exposed over most of the surface, and the edges are still rough and uneven. The other side has parallel oblique pressure flaking similar to that on seen 
on the Lot 1 and Lot 24 triangular arrow points. It is made from a pale gray, translucent chert with a few white inclusions.

Lot 9 is another thin $(4 \mathrm{~mm})$ biface fragment that might be from an unfinished arrow point, perhaps the proximal portion of a preform because the edge opposite the break is straight although curiously at an angle. Both sides are completely covered by pressure flake scars, one side by random flaking and the other with horizontal parallel flaking. It is made from a brown translucent chert similar to Edwards with lighter brown mottling.

\section{Arrow Point Blank N=1 (see Figure 9)}

Lot 2 is an interior or tertiary flake with moderate retouch around its edges. It measures $30 \mathrm{~mm}$ in length, $18 \mathrm{~mm}$ wide, and $4 \mathrm{~mm}$ in maximum thickness near its proximal end where the bulb of percussion in still evident. One lateral edge shows bifacial retouch and the striking platform and some of the bulb have been removed by pressure flaking. The blank was probably struck from the core using a hard hammer because of the flake's outline and prominent bulb, and terminated from the core with a slight hinge fracture. The flake is made from a fine-grained, translucent brown chert, and is the right size and shape to produce a triangular arrow point similar to those found in the Late Component area. Still, it could also have been worked into a Scallorn or other style point.

\section{Informal Unifaces $N=5$}

These five unifaces are all made on thick flakes and have one or more steep working edges. Lot 5 is a thick primary flake with a steep working edge along both lateral edges and is made from a light brownish gray chert with reddish brown cortex. Lot 6 is a thick tertiary flake with short, steep retouch along one lateral edge and along the distal edge meeting at a right angle. The material is an opaque, fine-grained chert primarily gray in color with lighter gray and light brown mottling. Lot 25 is a roughly triangular uniface resembling in basic form the end scrapers described above but with three separate working edges located on the corners. The interior surface of the original flake is completely flat without visible compression rings. The tool is made from opaque purplish chert with white mottling and no cortex. Lot 26 is a hard hammer secondary flake with steep retouch along one lateral edge. The worked edge is slightly concave. It is made of fine-grained, dark gray chert with light gray inclusions, and the cortex is brown. Lot 39 is a large, moderately thin primary flake whose distal edge has been unifacially worked into a convex cutting or scraping tool. The material is a fine-grain dark grayish brown Edwards-like chert with light gray mottles. The cortex is brown with white patches. This tool was recovered from the upper $10 \mathrm{~cm}$ of Unit 5 . Lot 45 is a non-cortical flake fragment with one lateral edge worked into a steep bevel. It is possibly a fragment from a more formal-type side scraper. The material is a translucent, light brown chert with white inclusions.

\section{Edge Modified flakes $N=3$}

These are hard hammer flakes, two tertiary and one secondary, with retouch along one lateral edge. The modified edges of two these tools (Lots 48 and 49) are straight, while that of the third (Lot 50) is concave. The two with straight worked edges are made from opaque light grayish brown 
fine-grained chert with lighter mottles, and the one with the concave edge is made from a slightly translucent brown chert of medium texture.

\section{Red pigment stone (Figure 10)}

This is a chunk of hematite-rich iron ore measuring 40-x-37-x-18-mm. The stone has clearly been modified in that large areas are covered by shallow grooves and striations. These striations are especially prominent where the surface has a redder hue. The surface color of the rock ranges from 10YR 4/6 (red) to 2.5YR 4/3 (reddish brown).

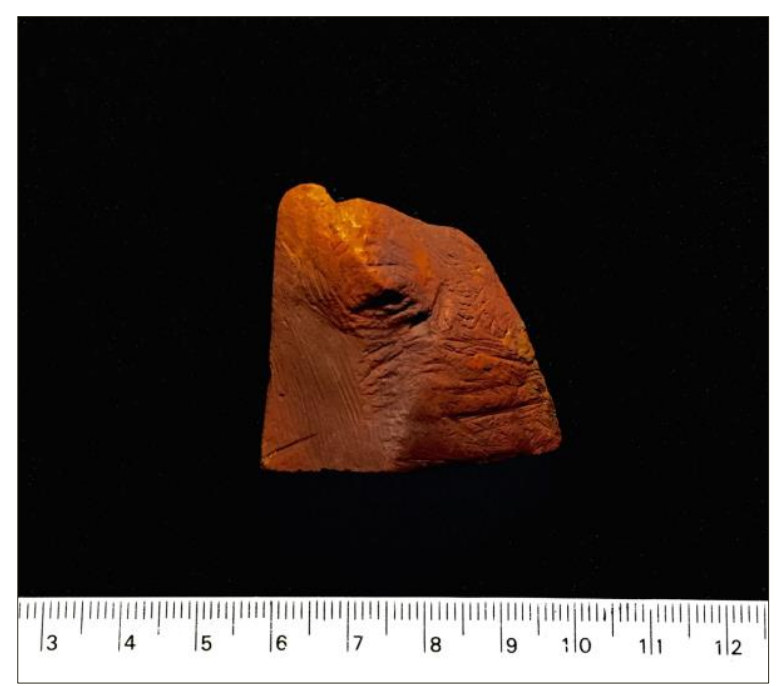

Figure 10. Red hematite pigment stone (Lot 14) with striations and grooves collected from the Late Component area, $41 \mathrm{SS} 186$.

\section{Core $N=1$}

A small, multi-directional core was recovered from Level $1(0-10 \mathrm{~cm})$ of Unit 1 measuring 4-x-3.5$\mathrm{x}-1.5-\mathrm{cm}$. It is made from fine-grained opaque chert that is heavily mottled in different shades of brown and gray. The chert has a slight luster as though it has been heat-treated, and cortex is present along one side. At least seven flake facets are visible running in different directions from three separate striking surfaces.

\section{Debitage}

A small amount of debitage was observed on the surface of the Late Component area, but only the debitage recovered from the test units was collected and counted. Most of the collected debitage consisted of non-flake shatter and the distal portions of thick hard-hammer flakes. Complete and proximal parts of flakes made up only a small percentage of the debitage and none of these are blades. No thin, soft hammer flakes were recovered from the five units placed in the Late Component area. Debitage recovered from the 1/8- and 1/16-inch screen generally consisted of shatter with flakes or flake fragments representing less than half the count.

Debitage recovery for all subsurface tests from the 1/4-inch screen is shown in Figure 3 using graduated symbols. The recovery shown is for the upper $20 \mathrm{~cm}$ of soil only from where most of the debitage was recovered. Recovery (1/4-inch screen) from the 4 shovel tests placed in the Late Component area ranged from 1 to 5 pieces of debitage with an average of 3 pieces. Recovery (1/4-inch screen) from the 18 shovel tests placed outside the Late Component area, excluding the three in the shell midden, ranged from none up to seven, with an average of 2.5. There appears to be little difference in the amount of debitage from the 1/4-inch screen from the two areas. The five 1-x-1$\mathrm{m}$ units in the Late Component area recovered from 16 to 41 pieces of 1/4-inch screened debitage in the upper $20 \mathrm{~cm}$ of soil, with an average of 29 pieces. Fairly low when compared to the 256 pieces of debitage recovered from the upper $20 \mathrm{~cm}$ in the unit placed over the shell midden. 
The upper level of Unit 1 in the Late Component area was screened through1/16-inch mesh, and recovered 110 pieces of debitage. The 1/8-inch screening of two other units in the Late Component area ranged from 11 to 20 pieces of debitage per level with an average of 16 pieces. The fine screening was primarily done to collect any small historic-period artifacts like glass beads, but the lithic recovery shows a fairly high frequency of debitage less than 1/16-inch.

\section{Other Cultural Materials}

Other non-lithic, non-ceramic cultural material observed in the Late Component area included some widely scattered burned rocks and few mussel shell fragments. This is the kind of material that is very common in the Austin component at Wilson, and may not belong to the later occupation.

\section{Isolated Toyah Artifact}

A Toyah end scraper was noted the surface of the terrace slope outside the southwestern edge of the site, and about $100 \mathrm{~m}$ south of the Late Component area. It is a uniface made from brown Edwards chert and, while similar in size, does not resemble any of the Late Component examples in workmanship or material. The tool is more carefully knapped and has no trace of cortex on its exterior surface. This is the only evidence that LUAS found of Toyah outside the Late Component area.

\section{LUMINESCENCE RESULTS}

Three of the seven bone-tempered sherds were sent as a single sample to James Feathers of the University of Washington's Luminescence Laboratory for luminescence dating. The lab required the ceramic samples to be at least $3 \mathrm{~cm}$ in diameter and $0.5 \mathrm{~cm}$ thick. This thickness is necessary because $0.2 \mathrm{~cm}$ from all outer surfaces must be removed to eliminate areas of the sample that were exposed to light and beta radiation. The three sherds, each measuring about $1-\mathrm{x}-2-\mathrm{x}-0.5 \mathrm{~cm}$, had to be combined into one sample to provide the necessary volume for the analysis. The sherds were collected from the surface in the central and northern parts of the Late Component area (see underlined sherd locations in Figure 4).

Feather's analysis included both thermoluminescence (TL), a technique that has long been used to date ceramics, and optically stimulating luminescence (OSL), which is now being used to date heated materials and has the added benefit of requiring a smaller sample size (Feathers 2003:1496). Luminescence dating involves calculating the elapsed time since the samples were last heated to above about $500^{\circ} \mathrm{C}$ (Feathers 2003:1495), a temperature that would have been exceeded when the pottery was fired (Rice 1987:86), or in the case of OSL, when the sample was last exposed to light. Light and heat have a zeroing effect on the sample, after which energy buildup starts all over again at a estimable rate due to the bombardment of radiation from the soil and within the sample itself, as well as from comic radiation. In the lab, the sample is reheated or exposed to light and this energy is released in the form of light. The elapsed time in years since the zeroing effect is then calculated based 
on the intensity of the light emitted. The analysis resulted in a TL calendar date of AD $1350 \pm 90$ and

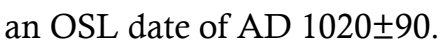

Feather's report is included in the Appendix, where he concedes that these dates are not in agreement. He reconciles this by stating that the TL age is probably underrepresented (i.e., too young) because the amount of anomalous fading could not be estimated due the small sample size. Anomalous fading is the loss of stored electrons from minerals, particularly feldspars, at ambient temperatures resulting in a younger date. On the other hand, Feathers states that the OSL is possibly overrepresented (i.e., too old) because the dose recovery test used to validate the single-aliquot regenerative dose (SAR) procedure showed that the recovered dose was a little higher than the given dose. Therefore these dates must bracket the true date of the sample, placing it between AD 930 and 1430. The latter part of this range would place the Late Component in the early Toyah period, considered to begin around AD1350 or later for the western Edwards Plateau and perhaps earlier to the east (Carpenter 2012:212-213).

An accurate calculation of the dose rate, that is the amount of radiation the sample received per year, is critical for getting accurate date. One source of error includes the estimate of the moisture content of the sample (Duller 2008:19). The greater the water content of the sherd the more it is shielded from radiation. Feathers estimated the sample's moisture content at 10 percent, which reflects arid conditions, but the calculation was made as if it had 3 percent moisture. This would decrease the OSL age by 70 years, making the calendar date AD 1090 \pm 90 .

Another source of error comes from determining the average cosmic radiation dose the sample received each year. If the sample was buried by sediment it would be protected from such radiation, and not taking this into account will result in an age underestimation (Duller 2008:19). We can assume that because of its geological position on an ancient land surface, the Wilson site sample was either on the surface or buried by only a few centimeters of soil since it was discarded centuries ago. However, we cannot be absolutely sure that the sample was not buried deeper over most of this time. The cosmic radiation represents only a small percentage of the total radiation, so any miscalculation does not usually result in large errors (Duller 2008:19). In any case, miscalculation of the cosmic radiation dose doesn't really explain the early date on the Wilson site sample because deep burial of the sample would create an underestimation, not overestimation of the age.

\section{DISCUSSION}

The Wilson site's Late Component was investigated to find evidence to support a post-1700 date inferred by the presence of Guerrero-like points, however the fieldwork found no articles of European manufacture, gunflints, or other material identifiable to the seventeenth or eighteenth century. Although we can't rely on the luminescence dating of a single ceramic sample, the results do not support a post-1700 date and in fact would place the Late Component in the early part of the Toyah period, if not before.

At the same time, no Perdiz points were found, so Wilson does seem to be an anomaly as far as Toyah sites go. Still, we only excavated a very small sample of the plowzone, less than one percent of 
the Late Component area, and it is possible that Perdiz points are buried there. However, there is no good explanation for why plowing and other disturbances would expose only triangular points and not Perdiz points, if in fact they were ever there. It should also be noted that nearly all the diagnostic artifacts were recovered from the surface, while subsurface artifact recovery was very light in the Late Component area, with only two diagnostics being recovered from the five $1-\mathrm{x}-1 \mathrm{~m}$ units and four shovel tests. We would have had to excavate possibly 50 more test units to match the sample size exposed on the surface.

The Late Component lithic assemblage appears to be associated with bison hide processing, including the large end scrapers (Johnson 1994:117), the flake drill (Johnson 1994:139), and perhaps the hematite pigment stone (Dubreuil and Grosman 2009). The data can be interpreted as representing a small task force, presumably from a larger residential group, spending time on that spot defleshing hides and repairing weapons. Perhaps they had an olla there to provide water so they would not have to walk $400 \mathrm{~m}$ to the river for a drink. Their stay appears to have been brief, as indicated not only by the small site area, but also the low frequencies of debitage and artifacts in general. The debitage recovered from 1/4-inch screening consists mostly of small hard hammer flakes that could have derived from fashioning the bits on the end scrapers. The material for the scrapers most likely came from the nearby terrace slope where chert gravels of suitable size are abundant. Soft hammer flakes are absent from the Late Component area, so no thin bifaces were being manufactured. It doesn't appear they lingered long at this location. This scenario presupposes that the Late Component is not part of a single large aggregation of rancherias spread out along the San Saba River (see Kenmotsu and Arnn 2012:33-37). Other offset contemporaneous camping areas in the immediate area cannot be ruled out entirely because the LUAS survey was limited to the Wilson property and the adjacent properties to the north.

\section{The Luminescence Dating}

The archaeological event we want to date is the occupation at Wilson by people using the unnotched triangular arrow points, but luminescence is actually dating the manufacture of the pottery. As Feathers (2003:1495) points out, the dating event and the event targeted by luminescence might be widely separated in time. At Wilson, such a situation might have occurred if late aboriginal people using triangular points happen to visit the exact spot where early Toyah people left ceramics. However, the chance of this happening seems fairly remote because of the close spatial relationship between the arrow points and sherds (see Figures 3 and 4).

There is also the possibility that post-1700 aboriginal people somehow acquired an old pot manufactured by early Toyah people and brought it to Wilson where it was eventually broken. But the chance of an earthenware pot surviving for 400 years in Late Prehistoric central Texas, by whatever scenario that can be imaged, must be very slim. A more plausible scenario is that later people collected sherds from an old Toyah campsite to repurpose them at Wilson, perhaps as hide scrapers. However, there is no evidence of use-wear on any of the sherds. 


\section{Guerrero Points and Wilson}

The argument that Wilson is a Spanish Colonial-era site currently rests solely on the resemblance of the Late Component's arrow points to Guerrero points, but is there any way to be more confident in this typing? The shape or outline of the Wilson arrow points is no real help because Guerrero points are known to be quite variable in this regard even when excluding the lanceolate variety found southeast of the Edwards Plateau (Turner et al. 2011:195). For this reason, Guerrero point typing is heavily dependent on Spanish Colonial context, which we don't have at Wilson.

In any case, it might be informative to see how the Wilson arrow points compare to Guerrero points in width and thickness with the understanding that such factors are often influenced by material and other non-cultural factors (Whittaker 1994:270). Another problem to consider with this analysis is that unfinished Guerrero points are probably included in the samples, skewing the data towards wider and thicker. Figure 11 shows a scatter-plot graph comparing maximum thickness and maximum width of the Wilson examples with previously-reported metric data of arrow points from five Spanish missions: San Jose (Tomka 1999:Table 1), San Antonio de Valero (Lohse 1999:Table 3), San Bernardo North (Inman 1997:Table 7), Espiritu Santo in Goliad (Inman 1997:Table 20), and San Juan Bautista (Inman 1997:Table 2).

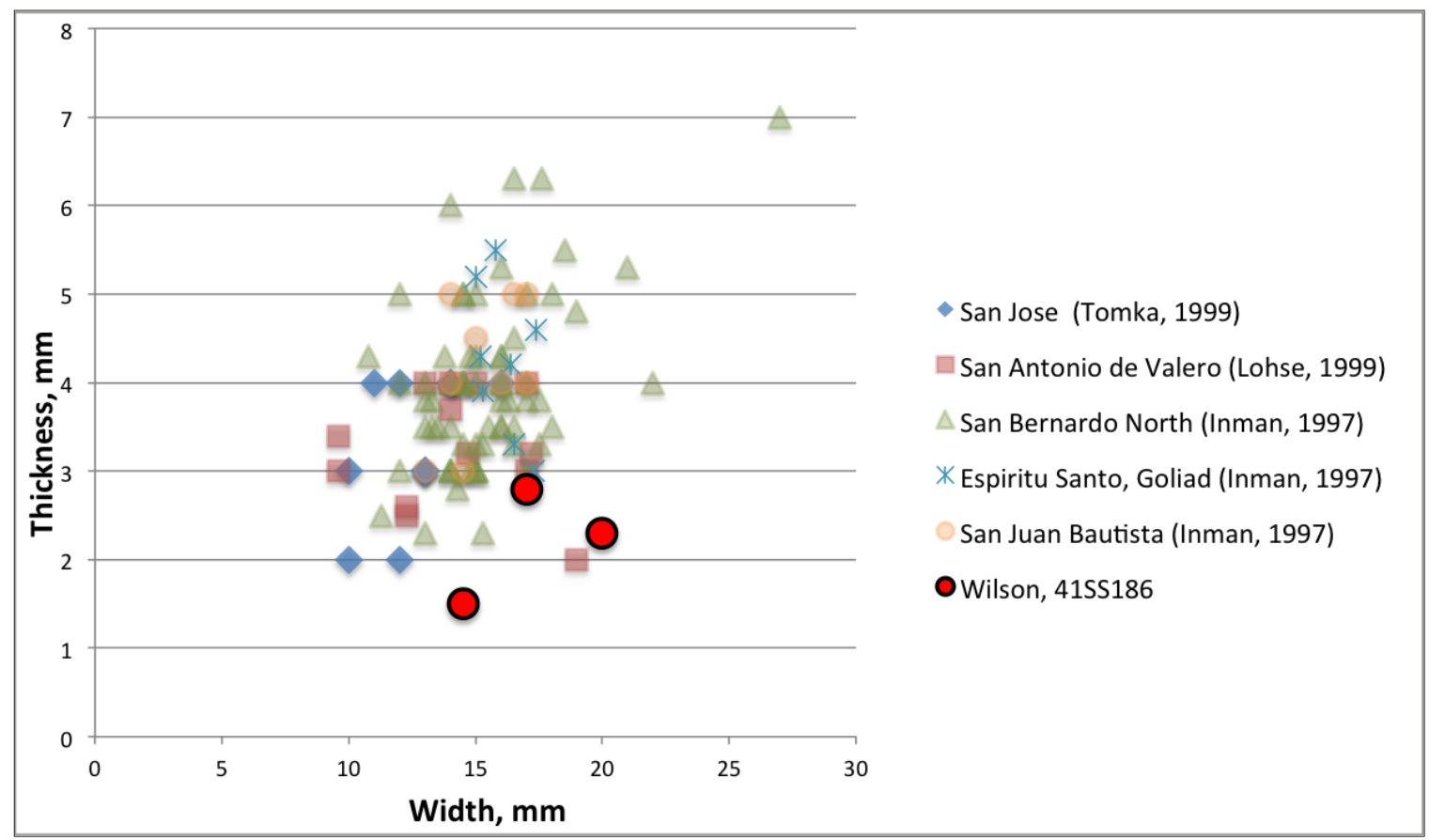

Figure 11. Scatter plot with transparent graph points representing individual Guerrero points from five south Texas Spanish missions along with the three Wilson arrow points plotted by width and thickness.

The Figure 11 graph visually shows that the Wilson arrow points fall at the extreme thin end of the thickness range, and one Wilson example (Lot 7) is thinner than any of the measured mission points. In maximum width, the Wilson examples tend to be rather wide, but there are a few mission examples that are even wider. Considering just these two attributes, width and thickness, the Wilson 
arrow points tend to cluster more with the San Antonio mission Guerrero points, especially those from San Antonio de Valero. What we can take from this is that the Wilson examples for the most part fall within the range of Guerrero points in terms of thickness and maximum width, but are thinner and to some extent wider than most Guerrero points.

\section{Triangular Arrow Points in Toyah Components}

Triangular arrow points are known to occur in small percentages along with Perdiz points in many Toyah components. In fact, an unnotched triangular form was included in the first conception of the Toyah culture formulated by J. Charles Kelly (1947:122-124) using data from Lehmann Rockshelter in Gillespie County. Kelly (1947:122) gave this arrow point form the type name of "Fresno Triangular Blade" and triangular arrow points found in Toyah components are still often referred to as Fresno points. The point Kelly (1947:Plate 13) illustrates as an example of this type looks a lot like a preform, which brings up one of the problems with the Fresno type: it has been assigned to unfinished arrow points (Turner et al. 2011:191), especially unfinished Scallorn (Shafer 2006:17) and Harrell/Washita points that had yet to be notched (Speth and Newlander 2012:166167). Despite this concern, the type name is used throughout the state (Prewitt 1995:Figure 20), presumably for both unfinished points as well as finished triangular points, such as a form on the Texas coast (Turner et al. 2011:191). Fresno is commonly used for triangular points in the Texas Panhandle (Boyd 1997:427-428; Hughes and Willey 1978:29), even for forms that other researchers would call Talco-like points (Boyd 1997:428). When archaeologists assign a type name to a particular triangular arrow point form, it is based to a large degree on geographical location and whether or not it has historic context. There are no clearly agreed on morphological traits that distinguish most triangular arrow point types.

The Wilson site triangular points do not appear to be preforms because they are all extremely thin with well-trimmed edges and have distinctive break patterns-bending fractures above the hafting area - that suggest they broke while being used as projectile tips (see Figure 5). In the absence of clear impact fractures, we can never be absolutely sure that any triangular form is not an unfinished point, but the simplest interpretation for the Wilson site examples is that they are in a finished state.

While finished triangular arrow points have been found in many Classic Toyah components, they have not been reported from some of the major Toyah excavations, including Kyle Rockshelter (Jelks 1962), Buckhollow (Johnson 1994), Rush (Quigg and Peck 1995), Flatrock Road (Thompson et al. 2012), and Little Paint (Carpenter et al. 2012). So just how common are Toyah components with triangular arrow points? To get a rough idea of the frequency and distribution of such sites, keyword searches on the Texas Historical Commission's Texas Archeological Sites Atlas were used to identify sites where Perdiz points and triangular arrow points co-occur, keeping in mind that the latter could in some cases be preforms for notched and stemmed points. It should also be pointed out that the Sites Atlas data are almost exclusively from reconnaissance- and survey-level investigations and as such they represent only a small sample of cultural material from these sites. The use of this database is perhaps the only way to get a broad look at many sites over a broad geographical area. 
The Boolean searches used were: triangular AND Perdiz; Fresno AND Perdiz; and Guerrero AND Perdiz. These searches covered the three most common names used by archaeologists for triangular arrow points in the Toyah region. The relevant sections of each of the selected site forms were read to make sure that the keywords refer to arrow point types and not other usages of these terms (e.g., Fresno Creek). "Leon Plain" and "bone tempered" were also used in similar searches in place of "Perdiz" but had few matches.

The keyword searches found a total of 40 matches that identify sites where both triangular arrow points and Perdiz points have been reported (Table 2). To this number seven more Toyah sites can be added that are known to have triangular arrow points: 41JW8 (Black 1986); 41TG91 (Creel1990); 41WM437 (Prewitt 2012; Rush 2013); 41CC131, 41CN95 (Treece et al. 1993); 41ED28 (Quigg et al. 2008:238, 243) and 41MN33 (Arnn 2012:221). Figure 12 shows the locations of these 47 sites, 23 of which occur within the Classic Toyah area and another six in Johnson's (1994:Figure 105) shared cultural region (called a "Shared Area") immediately to the north. This is a relatively small number considering that a search for "Perdiz" alone will have over 800 matches statewide, over half of those being inside the Classic Toyah area. Therefore roughly five percent of Classic Toyah sites are reported to contain triangular points. The actual percentage is probably higher because triangular forms typically make up only a small fraction of the arrow points in Classic Toyah sites and are less likely to be reported.

Still, Toyah sites with triangular arrow points (including Fresno and Guerrero) are widely reported across the region but most have been recorded south of the Edwards Plateau (see Figure 12). A concentration of such sites can be seen near the Rio Grande River, with the arrow points perhaps representing Zapata, Guerrero, or unnamed south Texas triangular forms, and the southern coastal region where Starr and McGoin arrow points are common types (Black 1986:64). Another, looser cluster is seen in the northern half of the Classic Toyah area and to the north in the shared cultural area. Presumably, these triangular points are related to types commonly found in Garza and perhaps Henrietta complexes. Importantly, the southern half of the Edwards Plateau is nearly devoid of such sites, with the exception of Varga and two sites on the Balcones Escarpment where the site forms state that possible Guerrero points were identified in large artifact collections (see Figure 12).

While Perdiz and triangular points do often co-occur in the northern and southern areas of the Toyah range, how common are sites like Wilson where triangular points are the only Late Prehistoric II (post-AD 1200) arrow point types reported? Another Texas Archeological Sites Atlas search was made using the following keyword search criteria for archaeological sites: Fresno AND NOT "Fresno Creek" AND NOT Perdiz AND NOT Harrell AND NOT Harrel AND NOT Washita AND NOT Garza AND NOT Lott. The search produced 137 matches statewide with duplicates removed (see Table 2). As with the previous search, this one was done only to get an idea of the prevalence and geographic distribution of such sites, particularly in the Classic Toyah area. Many of these reported Fresno points are probably unfinished notched or stemmed points. Figure 13 shows the frequency of such reported sites using graduated colors for the counties. As might be expected, concentrations of these sites are found in south Texas and in the Panhandle. 
Table 2. Archaeological sites where Fresno is the only reported Late Prehistoric II arrow point type, based on keyword searches on the Texas Historical Commission's Texas Archeological Sites Atlas.

\begin{tabular}{|c|c|c|c|}
\hline 41AD9 & 41FL2 & 41LS13 & 41RW19 \\
\hline 41AN26 & 41FL5 & 41LU40 & 41SE18 \\
\hline $41 \mathrm{BI} 38$ & 41FY546 & 41MD41 & 41SE294 \\
\hline 41BK37 & 41GA57 & 41ML42 & $41 S F 47$ \\
\hline 41BL355 & 41GL65 & 41MO35 & $41 S F 56$ \\
\hline 41BR222 & 41GL98 & $41 \mathrm{MO} 037$ & 41SP72 \\
\hline 41BR269 & 41GR137 & 41MO96 & 41SP118 \\
\hline 41BR332 & 41GR432 & $41 \mathrm{MO} 245$ & 41SR325 \\
\hline 41BR405 & 41GR722 & 41MV332 & $41 S S 14$ \\
\hline 41BS78 & $41 \mathrm{HC} 11$ & $41 \mathrm{MY} 1$ & 41SW15 \\
\hline 41BT60 & 41HF35 & 41MY5 & 41TE577 \\
\hline 41BX626 & 41HF37 & 41NU64 & 41TE588 \\
\hline 41CAS18 & 41HF38 & 41NU103 & 41TV199 \\
\hline 41CAS19 & 41HF117 & 41NU193 & $41 \mathrm{TY} 9$ \\
\hline 41CAS26 & 41HG4 & 41NU235 & 41VT4 \\
\hline 41CB47 & 41HG5 & $410 c 6$ & 41VV161 \\
\hline $41 \mathrm{CB} 77$ & 41HG64 & $410 C 32$ & 41WB126 \\
\hline 41CE25 & 41HG179 & 410L120 & 41WB136 \\
\hline 41CF147 & 41HP171 & 410L243 & 41WB361A \\
\hline $41 \mathrm{Cl} 91$ & $41 \mathrm{HS} 15$ & 410L289 & 41WB414 \\
\hline $41 \mathrm{Cl} 94$ & 41HT4 & 410L293 & 41WB525 \\
\hline 41CJ48 & $41 \mathrm{HX} 4$ & 41PS28 & 41WD464 \\
\hline 41CJ69 & 41HY222 & 41PS36 & 41WD589 \\
\hline $41 \mathrm{CN} 67$ & 41KE44 & 41PS302 & 41WM1186 \\
\hline $41 \mathrm{CS} 88$ & $41 \mathrm{KM} 123$ & 41PS1101 & 41ZP99 \\
\hline 41CU402 & 41KR85 & 41PT50 & 41ZP168 \\
\hline 41CV1598 & 41KR97 & 41PT112 & \\
\hline 41DA1 & $41 \mathrm{KT} 42$ & 41PT194 & \\
\hline 41DA6 & 41LE1 & 41PT378 & \\
\hline 41DA8 & 41LE5 & 41PT379 & \\
\hline 41DN81 & 41LE14 & 41RB15 & \\
\hline 41DN188 & 41LE17 & 41RB64 & \\
\hline 41DN290 & 41LL311 & 41RB158 & \\
\hline 41DN310 & 41LL321 & 41RB161 & \\
\hline 41EA17 & 41LL329 & 41RD69 & \\
\hline 41EP5403 & 41LL349 & 41RN90 & \\
\hline 41FA52 & 41LS12 & 41RN113 & \\
\hline
\end{tabular}




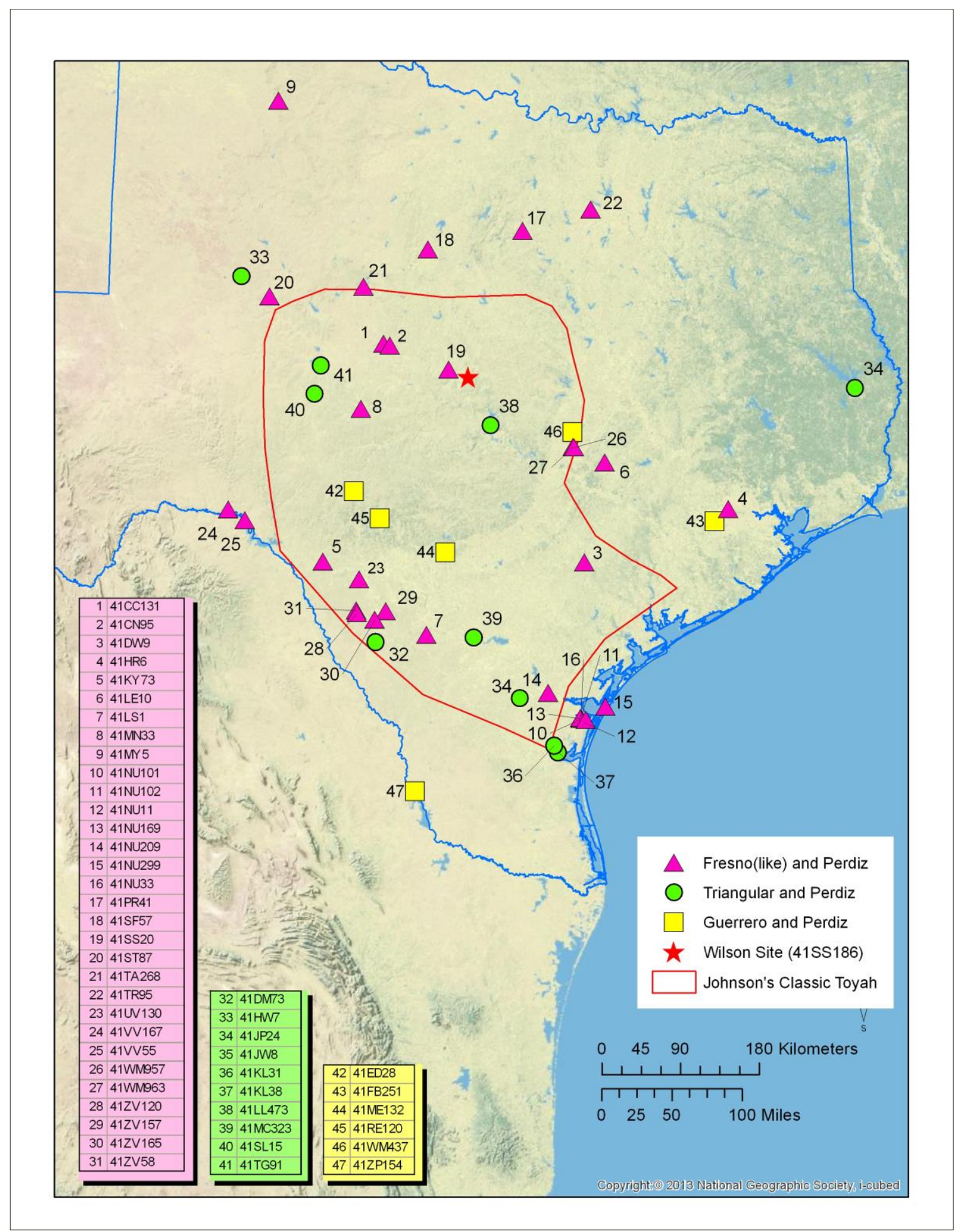

Figure 12. Map showing sites with the co-occurrence of Perdiz and triangular arrow points. Data are based on keyword searches in the Texas Archeological Sites Atlas. 


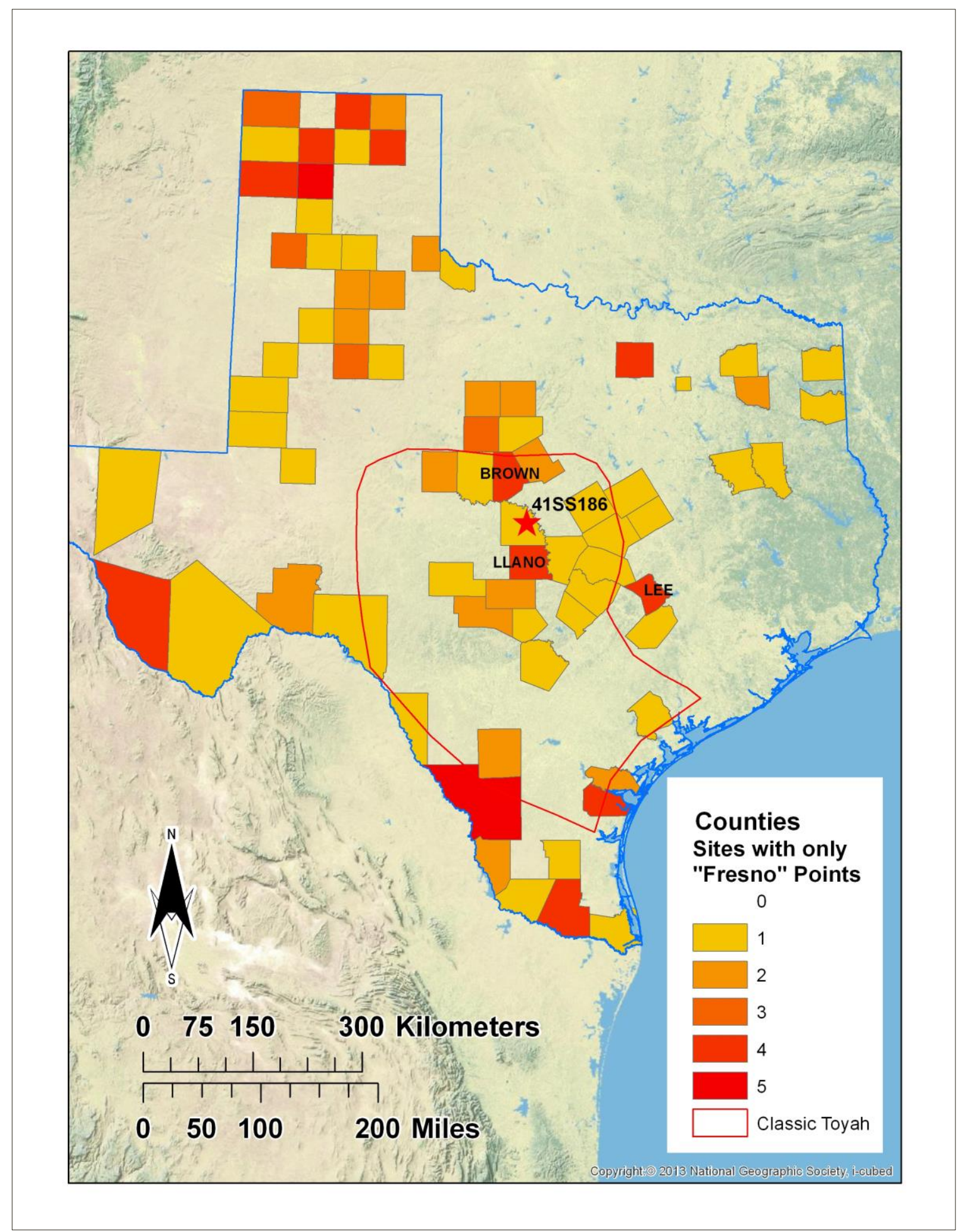

Figure 13. Texas counties color-graduated for frequency of sites where Fresno points are the only reported Late Prehistoric II arrow points. Data are based on keyword searches in the Texas Archeological Sites Atlas.

Within the Classic Toyah area, there is an unexpected concentration near the center in Llano County (see Figure 13). The previous search for the co-occurrence of Perdiz and triangular points did not come up with many sites in this area (see Figure 12). Furthermore, no other Toyah diagnostic 
artifacts were recovered from these sites, so it's possible the Fresno points might actually be Scallorn point preforms. Interestingly, all the Llano and Gillespie County sites with only Fresno points were recorded during the survey for Enchanted Rock State Natural Area (Assad and Potter 1979), so perhaps this unique natural feature attracted distant peoples on pilgrimages or for other ritual purposes.

The concentration seen in Brown County (see Figure 13) on the northern edge of the Classic Toyah area is more expected being closer to the Southern Plains where triangular arrow points are common (Boyd 2012:135-136). However, none of these sites have other reported Toyah material so perhaps here too the Fresno points are actually preforms. The concentration seen in Lee County east of the Classic Toyah area has one site in particular, 41LE5 on West Yegua Creek, that might have an assemblage similar to Wilson and possibly of historic age. Four Fresno points were reported there in addition to a fair amount of ceramic sherds, some with bone temper and others with sand.

\section{Harrell/Washita Points and Wilson-style Arrow Points}

As discussed in the previous section, around five percent of sites with Perdiz points in the Classic Toyah area also report triangular points. Some of these triangular points could be preforms but some could be finished triangular arrow points similar to those at Wilson. Such triangular points are known from at least two Classic Toyah sites: 41TG191 in Tom Green County (Creel 1990:Figure 43) and 41LL473 in Llano County. These arrow points have concave basal edges of varying depth, straight to slightly concave or convex lateral edges, maximum width at the base, and often oblique parallel flaking patterns. Notably, Harrell points were also recovered from 41TG91 and 41LL473, in addition to Perdiz points.

If there is a strong association between Harrell points and triangular arrow points in Classic Toyah sites, that might reinforce a northern origin for the Wilson site triangular points. At 41TG91, the Toyah component probably represents multiple occupations, especially in Area A (Creel 1990:227) where two Harrell points were recovered from the upper Toyah zone of Unit 11 (Creel 1990:98). In the unit diagonally adjacent, three triangular arrow points were recovered from roughly the same elevation. One of these triangular points was reconstructed from two fragments and is perhaps the one shown in the photo (Creel 1990:Figure 3A). This particular point is very similar to the Lot 1 Wilson site triangular point in outline and flaking pattern. From this we not only get a fairly good association between a Wilson-like arrow point and Harrell points, but it is also noteworthy that these points appear late in the Toyah sequence at 41TG91. Further evidence of the association between a Wilson-like triangular arrow point and Harrell points can be seen at 41LL473, a small Toyah camp $90 \mathrm{~km}$ (55 miles) south of Wilson in Llano County.

Site 41LL473 is located in a canyon near the confluence of the Llano and Colorado Rivers. It was surveyed with shovel testing by LUAS in 1995 and 1996 and has never been reported on other than the TexSite form. In addition to the triangular point, 41LL473 also yielded a Perdiz point (Figure 14), and a side-and basal-notched arrow point (a typical Harrell point) that the foreman had found earlier.

No aboriginal ceramics were found, and the only other Toyah tool recovered was a beveled biface 
fragment. The shovel tests recovered moderate amounts of mussel shell but only a few small bone fragments despite apparently good conditions for preservation. The site probably represents a single visit, or a few nearcontemporaneous visits, because of the low artifact density and its remote location halfway up the side of a steep escarpment. Therefore, it would appear that these three point styles were used contemporaneously.

The co-occurrence of Perdiz and Harrell/Washita is not unusual in Johnson's

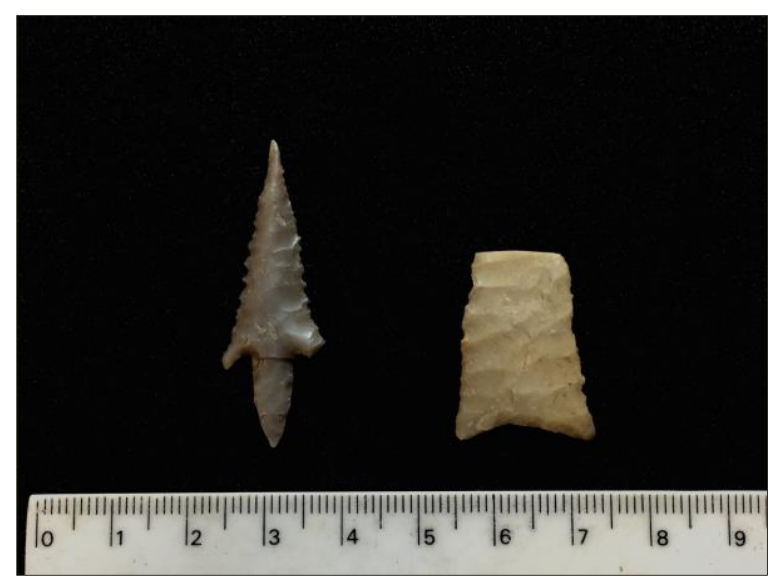

Figure 14. Arrow points recovered from 41LL473. shared cultural area and in Boyd's (2012:134-136) northern Toyah area, but how about the Classic Toyah area to the south? How far do such sites extend into this area? A keyword search (Perdiz AND Harrell OR Perdiz AND Harrel OR Perdiz AND Washita) on the Texas Archeological Sites Atlas found 26 matches (Table 3). Figure 15 visually shows that these sites extend over the northern half of the Classic Toyah region without the bifurcated distribution seen with the co-occurrence of Perdiz and triangular points. Sites with all these arrow point forms (Perdiz AND Harrell AND Fresno OR Perdiz AND Harrel AND Fresno OR Perdiz AND Washita AND Fresno) have not been reported as often with only 6 matches in the Texas Archeological Sites Atlas (Table 4). They have a more restricted range as shown in Figure 15 with 41TG91 and 41LL473 included.

Table 3. Archaeological sites reported to have both Perdiz and Harrell/Washita arrow points, based on keyword search on the Texas Historical Commission's Texas Archeological Sites Atlas.

\begin{tabular}{ll}
\hline $41 \mathrm{AN} 35$ & $41 \mathrm{PT} 383$ \\
$41 \mathrm{BS} 3$ & $41 \mathrm{RR} 65$ \\
$41 \mathrm{BS} 289$ & $41 \mathrm{RV} 5$ \\
$41 \mathrm{CK} 238$ & $41 \mathrm{SE} 16$ \\
$41 \mathrm{CK} 254$ & $41 \mathrm{SF} 57$ \\
$41 \mathrm{HW} 7$ & $41 \mathrm{SF} 62$ \\
$41 \mathrm{HW} 39$ & $41 \mathrm{SS} 20$ \\
$41 \mathrm{HY} 20$ & $41 \mathrm{ST} 87$ \\
$41 \mathrm{LL} 473$ & $41 \mathrm{SV} 60$ \\
$41 \mathrm{MT} 2$ & $41 \mathrm{TA268}$ \\
$41 \mathrm{MY5}$ & $41 \mathrm{TG} 69$ \\
$41 \mathrm{OC} 93$ & $41 \mathrm{WK} 48$ \\
$41 \mathrm{PP} 81$ & $41 \mathrm{WK} 78$ \\
\hline
\end{tabular}


Table 4. Archaeological sites reported to have Perdiz, Harrell/Washita, and Fresno arrow points, based on keyword search on the Texas Historical Commission's Texas Archeological Sites Atlas.

\begin{tabular}{l}
\hline 41BS289 \\
41MY5 \\
41SF62 \\
41SS20 \\
41ST87 \\
41TA268 \\
\hline
\end{tabular}

Considering their association with Harrell points in the northern part of the Classic Toyah region, the Wilson site arrow points likely have connections to some Southern Plains cultures where both side-notched and unnotched triangular points are common Late Prehistoric/early historic arrow point forms. In the 1600s, groups that formally resided in present-day Kansas and Oklahoma were moving south into Texas (Newcomb and Campbell 1982:36). These groups included Wichita-speakers, as well as Athabaskan-speakers, and the spread of triangular and side-notched arrow points into the northern Toyah region might be evidence of these migrations.

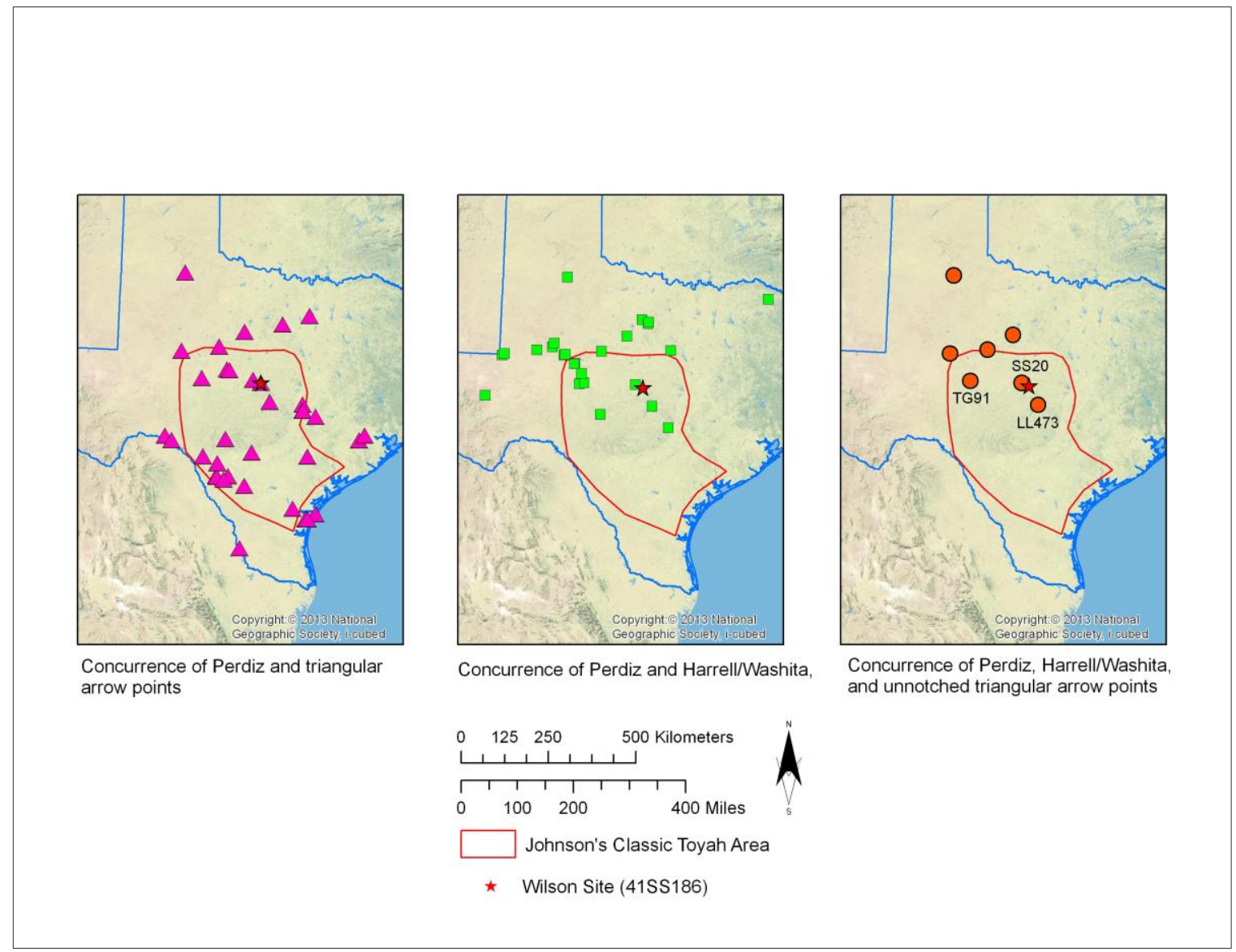

Figure 15. Distribution of sites with the co-occurrence of Perdiz and triangular arrow points (left), Perdiz and Harrell/Washita (middle), and Perdiz, triangular, and Harrell/Washita (right) based on Texas Archeological Sites Atlas keyword searches. 
Interestingly, two Spanish military expeditions from New Mexico into central Texas in the 1650s may have encountered migrants from the Southern Plains near the Wilson site (Arnn, personal communication, 2016). In 1650, the Martin-Castillo expedition visited the Jumano people in their lands along the Concho River in what is now Tom Green County (Kenmotsu 2001:28-29, Wade 2003:74). The Spanish, who had had contact with the Jumano since 1583, were in part motivated by trade, while the Jumano encouraged such Spanish visits in hopes of forming an alliance against hostile neighbors (Kenmotsu 2001:29). During their stay, the Spanish discovered freshwater pearls in the river and, more importantly, learned for the first time about the existence of the Tejas (Hasinai Caddo), a powerful and populous nation in east Texas that, along with the Jumano, was part of the Tejas Alliance (Arnn 2012:135). In an attempt to make contact with the Tejas, members of the Martin-Castillo expedition possibly in company with some Jumanos continued eastwards and southeastwards, a route that would have taken them through the lower San Saba River drainage area and through lands belonging to three nations: the Cuitoa, the Excanxaque and the Ayjado (Wade 2003:74, Arnn 2012:91-92). After reaching the edge of the Tejas territory, the expedition turned back without actually visiting any Tejas settlements, although they did meet a Tejas captain sent to learn the Spanish intentions (Wade 2003:74).

Four years later, another expedition led by Diego de Guadalajara visited the Jumano homeland to trade and collect freshwater pearls, and perhaps to make contact with the Tejas nation, who could potentially benefit Spanish interests in the region (Arnn 2012:92). After reaching the Concho River, the Spanish learned that the Jumanos were now at war with the three groups to their east, the Cuitoa, Excanxaque, and Ayjado, who blocked the direct route to the Tejas. Guadalajara sent a detachment of soldiers with some Jumano $125 \mathrm{~km}$ east of the Jumano lands, where they attacked a Cuitoa rancheria (Wade 2003:74). This rancheria was probably located somewhere in what is now eastern McCulloch or western San Saba County. After a day-long battle, the Spanish were forced to retreat back to the Jumano when learning that the Cuitoa would soon to be reinforced by their allies, the Excanxaque and the Ayjado, but they still managed to take over 200 Cuitoa captives and many bison, deer and elk hides (Wade 2003:74). Arnn (2012:92) points out that the large number of Cuitoa prisoners probably means they represented something larger than a band-sized social unit, and the large number of hides must indicate a thriving trade in that commodity. Also it is clear from the hostility between them and the Jumano that these three nations were not part of the Tejas Alliance.

The connection of the Cuitoa to the Southern Plains rests on their association with the Excanxaque (also spelled Escanjaque and Excanjaque), who were first encountered in northwestern Oklahoma by the 1601 Oñate expedition (Craddock and Polt 2013; Newcomb and Campbell 1982:30). Oñate's official report and the testimony of his soldiers state that the word "Excanxaque" was a peace greeting (Newcomb and Campbell 1982:30) and testimony from Miguel, an Excanxaque captive, indicated that these people actually called themselves "Aguacane" (Newcomb and Campbell 1982:36). Economically, they were similar to the Apaches, at the time living mainly by hunting bison and possibly practicing some agriculture, but unlike the Apaches they resided in unusually large settlements of 4,000 to 6,000 inhabitants, at least at the time of year (summer) of their encounter with Onate. Campbell and Newcomb (1982:37) suggest that the Aguacane were Wichita speakers based on the names of their settlements given by Miguel's testimony. Archaeologically, the Wheeler phase of 
western Kansas and Oklahoma is believed to represent in part the Aguacane/Excanxaque (Vehik 2002:40).

Campbell and Newcomb (1984) had strong reservations that the Cuitoa ever existed, noting that their only mention is found in Fray Alonso Posada's 1686 Report, which also happens to be the only Spanish document that specifically references the Martin-Castillo and Guadalajara expeditions. Posada's report also includes a description of the earlier Oñate expedition, where he substitutes the Ayjado for Excanxaque, and mentions the latter only in connection with the two 1650s expeditions. Posada, who was writing his report from southern Mexico, must have been receiving poor or misleading information on these expeditions (Newcomb and Campbell 1982). Campbell and Newcomb considered the Ayjado also suspect - the term in Spanish ("ahijado") means "adopted" and apparently used only to designate individual captives, not social groups, in the original Oñate documents.

Newcomb (1993:11-12) doubted any Spanish expedition ever reached central Texas during these years. However, Wade (2003:74-77) does present other evidence of Spanish expeditions into central Texas in the 1650s besides Posada, including statements by the Jumano leader, Juan Sabeata, and legal testimony given by two participants of these expeditions, Christoval de Anaya and Juan Dominguez Mendoza. Wade (2003:218) also suggests that the original documents concerning these expeditions may have been lost during the 1680 Pueblo Revolt. It is possible the 1654 Martin-Castillo expedition did initiate an attack on an aboriginal group east of the Jumano, but the participants may have been uncertain of their identity or the correct information never reached Posada. Cuitoa might be the actual name of these people since, unlike Excanxaque and Ayhado, this name doesn't occur in the Oñate documents. Only 30 years after the Martin-Castillo expedition, another Spanish expedition led by Mendoza and Fr. Nicolas Lopez must have traveled through western parts of the Cuitoa territory, yet accounts of this expedition make no mention of these people or their allies, the Excanxaque or Ayjado (Wade 2003:113, Figure 4.4). This is particularly strange because the accounts do name 55 other groups who either traveled with or were expected to meet up with the expedition (Wade 2003:115-116). The Cuitoa and their allies either moved away from their former territory or suffered a catastrophic population decline.

A more secure dating of the Late Component is needed before we can consider the Cuitoa or their allies as having anything to do with the Wilson site Late Component. Although the Cuitoa may not be from the same area as the Aguacane/Excanxaque, the Late Component lithic assemblage is similar to that of the Wheeler phase but the ceramics differ in tempering agent and surface treatment (Baugh 1986). Any newcomers would have had to make adjustments to their ceramic technology considering the different environments, but it seems more likely they would have obtained such vessels from nearby Toyah groups. Some Aguacane groups did eventually move southwards into Texas and possibly were known in latter historic times as the Tawakonis or Yscanis, or possibly the Yojuanes (Newcomb and Campbell 1982:38). Their movements kept them well east and north of the San Saba River drainage, probably to keep a safe distance from the Apache, who were moving south as well (Newcomb 1993). 
The Apache are another candidate for non-Toyah people who may have been responsible for the Late Component artifacts. In 1691, Fray Francisco Casañas listed 17 native groups that were considered enemies of the Hasinai, 14 or 15 of which lived to the west of the Caddo. Four of these were Apache groups: Apache, Sadammo, Caaucozi, and Mani, and one was Tonkawa (Tanquaay). All being enemies of the Tejas Alliance as well as being newcomers from the Southern Plains, they would not have used Perdiz points but instead almost certainly tipped their arrows with triangular or side-notched points.

During most of the eighteenth century, the Spanish frequently reported Apache groups specifically along the San Saba River area. In 1723, a Spanish punitive expedition attacked an Apache rancheria of 200 warriors 100 leagues north of San Antonio, which may have placed it on the San Saba River (Wade 2003:171). Nine years later, Colonial Governor Bustillo led an attack on a large rancheria on the San Saba River of 800 warriors belonging to at least three Apache nations: Apaches, Ypandi (Pelones) and Yxandi (Wade 2003:173-175). This the first Spanish reference to the Lipan (Ypandi) (Wade 2003:162). A third group present, the Chenti, were possibly Tejas because of the similarity to Cenis, the French term for the Hasinai Caddo (Minor 2009:33). By this time the Jumanos had allied themselves with their longtime enemy, the Apache, although no Jumanos were in the rancheria when it was attacked (Wade 2003:173). If the Late Component represents an Apache group, perhaps the bone-tempered pot was acquired from their Jumano allies. The San Saba River drainage remained one of the favored hunting grounds of Apache groups until late in the eighteenth century (Wade 2003:215).

\section{Concluding Remarks}

If we accept the luminescence results, the Wilson site Late Component represents an early Late Prehistoric II socio-cultural group that used triangular unnotched arrow points and not Perdiz points. This might have been before the establishment of the Toyah/Tejas social field when local people were just starting to adopt the Southern Plains toolkit. If this scenario is correct, then eventually the descendants of these people, and most groups on the Edwards Plateau, switched to constrictedstemmed Perdiz points. Earlier stemmed arrow point forms to the west and north of the Toyah region, either Deadmans (Boyd 1997:333-334) or Moran (Boyd 2012:148) are thought to be possible precursors to the Perdiz point. Carpenter (2012:237, 260-262) sees more evidence for the Perdiz form developing from the Bonham point, and for Toyah material culture to have first coalesced just east of the northern Edwards Plateau before spreading westwards. Radiocarbon dates (Carpenter 2012:212) may support this model, and the location of Wilson not especially far from this area is more reason not to discount the early luminescence dates.

If we dismiss the luminescence dating entirely, then the Late Component could date anytime during the Late Prehistoric II and Early historic periods. Getting a precise date is crucial if there is any possibility of determining the identity of the social unit who briefly occupied the Wilson site. If the component dates to the middle of the seventeenth century, we could possibly be dealing with members of the Cuitoa (or their allies who Posada may have mistakenly referred to as Excanxaque or Ayjado). If after 1700, then perhaps one of the Apache groups that were known to have hunted bison 
along the San Saba River until late in the century. Unfortunately at this time we have no other independent way of dating the site, but in the near future the RHX dating technique (Wilson et al. 2012) for low-fired ceramics might provide a more precise date that could lead us to the identity of the people who left behind this unusual artifact assemblage.

\section{ACKNOWLEDGEMENTS}

The fieldwork would not have been possible without the hard-working volunteers from the Llano Uplift who persevered through sometimes wet and cold conditions but always rock-hard soil. They were Doris Howard (TASN), Pat Hatten, Lisa Weatherford, Chelsea Seiter-Weatherford, Jan Huffstetler, Al Priest, Jim Taylor, Jim Wukasch, Paige Wukasch, Averi Wukasch, Corey Mullins (TASN), Holden Mullins, David Boyd, Patti Boyd, and guests Rebecca Whitley, and Rozanna Ruthuen. Buddy Whitley (TASN) was instrumental to the project, alerting us to the site's existence and acted as a go-between with the landowner in addition to assisting in the fieldwork. Of course none of this would have happened without Anna Wilson who knew there was something archaeologically important on her property and put up with us over many weekends.

\section{REFERENCES}

Arnn, John W.

2012 Land of the Tejas: Native American Identity and Interaction in Texas, A.D. 1300 to 1700. University of Texas Press, Austin.

Assad, Cristi, and Daniel R. Potter

1979 An Intensive Archeological Survey of Enchanted Rock State Natural Area, Llano and Gillespie Counties, Texas. Center for Archeological Research, The University of Texas at San Antonio, Archeological Survey Report No. 84.

Barnes, P.W.

1976 Geological Atlas of Texas: Brownwood Sheet. Bureau of Economic Geology, The University of Texas at Austin.

Baugh, Timothy G.

1986 Culture History and Protohistoric Societies in The Southern Plains. Plains Anthropologist 31(114) 167-187.

Black, Stephen L.

1986 The Clemente and Herminia Hinojosa Site, 41JW8: A Toyah Horizon Campsite in Southern Texas. Special Report 18. Center for Archaeological Research, The University of Texas at San Antonio. 
Boyd, Douglas K.

1997 Caprock Canyonlands Archeology: A Synthesis of the Late Prehistory and History of Lake Alan Henry and the Texas Panhandle-Plains, Vol. 2. Reports of Investigations, No. 110, Prewitt \& Associates, Inc.

2012 What Is Northern Toyah Phase? The Toyah Phenomenon on the Texas Southern Plains. In The Toyah Phase of Central Texas, Late Prehistoric Economic and Social Processes, edited by Nancy A. Kenmotsu and Douglas K. Boyd, pp. 128-151. Texas A\&M University Press, College Station.

Carpenter, Stephen M.

2012 Style, Function, and Evolution or Perdiz Points; Context and Function; Synthesis and a Revised Model of Toyah. In The Little Paint Site: A Classic Toyah Camp On The South Llano River, Kimble County, Texas. Prepared by Stephen M. Carpenter, Kevin A. Miller, Charles D. Frederick, Leslie G. Cecil,Mercedes C. Cody, and Abby Peyton. Texas Department of Transportation Environmental Affairs Division Archeological Studies Program Scott Pletka, Ph.D., Supervisor Archeological Studies Program Report No.148 and SWCA, Inc. SWCA Cultural Resources Report No. 12-429

Craddock, Jerry R. and John H. R. Polt

2013 Juan de Oñate in Quivira, 1601: the "Relación cierta y verdadera" and the Valverde Interrogatory. Cibola Project, University of California, Berkeley. http://escholarship.org/uc/item/7162z2rp

Creel, Darrell

1990 Excavations at 41TG91, Tom Green County, 1978. Publications in Archeology, No. 38. Texas State Department of Highways and Public Transportation, Austin.

Dubreuil, Laure and Leore Grosman

2009 Ochre and Hide-Working at a Natufian Burial Place. Antiquity 83(322):935-954.

Duller, G. A. T.

2008 Luminescence Dating: Guidelines on Using Luminescence Dating in Archaeology. Swindon: English Heritage

Feathers, James K.

2003 Use of luminescence dating in archaeology. Measurement Science and Technology 14:1493-1509.

Green, L. M. and Thomas R. Hester

1973 The Finis Frost Site: A Toyah Phase Occupation in San Saba County, Central Texas. Bulletin of the Texas Archeological Society 44:69-88.

Griffith, Glenn, Sandy Bryce, James Omernik, and Anne Rogers

2007 Ecoregions of Texas. Project report to Texas Commission on Environmental Quality. 
Hixson, Charles A., Daniel J. Prikryl, Glenn T. Goode, and Andrew F. Malof

2011 Archeological Test Excavations at 41SS178, LCRA San Saba River Nature Park, San Saba County, Texas. Cultural Resource Report No. 15, Lower Colorado River Authority, Austin.

Hudgins, Joe D.

1986 A Historic Indian Site in Wharton County, Texas. Bulletin of the Texas Archeological Society 55 (for 1984).

Hughes, Jack T. and Patrick S. Willey

1978 Archeology. In Archeology at MacKenzie Reservoir, edited by Jack T. Hughes and Patrick S. Willey. Pp. 24-31. The Texas Historical Commission, Office of the State Archeologist, Report 24.

Inman, Betty J.

1997 Lithic Artifacts of the Native Americans at the Spanish Colonial Missions, Guerrero, Coahuila, Mexico. MA Thesis, The University of Texas at Austin.

Jelks, Edward B.

1962 The Kyle Site, A Stratified Central Texas Aspect Site in Hill County, Texas. Department of Anthropology Archaeology Series 5. The University of Texas at Austin.

Johnson, Lee, Jr.

1994 The Life and Times of Toyah-Culture Folk: The Buckhollow Encampment, Site 41KM16, Kimble County, Texas. Office of the State Archeologist Report 38. Texas Department of Transportation and Texas Historical Commission, Austin.

Kelly, J. Charles

1947 The Lehmann Rock Shelter: A Stratified Site of the Toyah, Uvalde, and Round Rock Foci. Bulletin of the Texas Archeological and Paleontological Society 18:115-128.

Kelly, Robert L.

1995 The Foraging Spectrum: Diversity in Hunter-Gatherer Lifeways. Smithsonian Institution Press, Washington.

Kenmotsu, Nancy A.

2001 Seeking Friends, Avoiding Enemies: The Jumano Response to Spanish Colonization, A.D. 1580-1750. Bulletin of the Texas Archeological Society 70:23-44.

Kenmotsu, Nancy A. and John W. Arnn

2012 The Toyah Phase and the Ethnohistorical Record: A Case for Population Aggregation. In The Toyah Phase of Central Texas: Late Prehistoric Economic and Social Processes, edited by Nancy A. Kenmotsu and Douglas K. Boyd, pp. 19-43. Texas A\&M University Press. College Station. 
Kenmotsu, Nancy A. and Douglas K. Boyd

2012 The Toyah Phase in Texas: An Introduction and Retrospective. In The Toyah Phase of Central Texas: Late Prehistoric Economic and Social Processes, edited by Nancy A. Kenmotsu and Douglas K. Boyd, pp. 1-18. Texas A\&M University Press. College Station.

Lesser, Alexander

1961 Social Fields and the Evolution of Society. Southwestern Journal of Anthropology 17:40-48. University of New Mexico, Albuquerque.

Lohse, Jon C.

1999 Lithics from San Antonio de Valero Mission: Analysis of Materials from 1979 Excavations at the Alamo. Bulletin of the Texas Archeological Society 70:265-279.

McBrinn, Maxine

2005 Social Identities Among Archaic Mobile Hunters and Gatherers in the American Southwest. Archaeological Series 197, Arizona State Museum, University of Arizona, Tucson.

Minor, Nancy M.

2009 The Light Gray People: An Ethno-History of the Lipan Apaches of Texas and Northern Mexico. University Press of America, Maryland.

Newcomb, William W.

1993 Historic Indians of Central Texas. Bulletin of the Texas Archeological Society 64:1-63.

Newcomb, William W. and T. N. Campbell

1982 Southern Plains Ethnohistory: A Re-examination of the Escanjaques, Ahijados, and Cuitoas. In Pathways to Plains Prehistory: Anthropological Perspectives of Plains Natives and Their Pasts, edited by Don G. Wyckoff and Jack L. Hofman. Oklahoma Anthropological Society, Memoir 3, The Cross Timbers Heritage Association, Contributions 1.

Prewitt, Elton R.

1981 Cultural Chronology in Central Texas. Bulletin of the Texas Archaeological Society 52:65-89.

1995 Distribution of Typed Projectile Points in Texas. Bulletin of the Texas Archeological Society 66:83-174.

2012 Reflections on Evolving Perceptions. In The Toyah Phase of Central Texas: Late Prehistoric Economic and Social Processes, edited by Nancy A. Kenmotsu and Douglas K. Boyd, pp. 181203. Texas A\&M University Press. College Station.

Prikryl, D. Daniel, Andrew F. Malof, Charles A. Hixson, and Daniel K. Utley

2010 An Intensive Cultural Resources Survey of the Lower Colorado River Authority's Proposed San Saba River Nature Park Project, San Saba County, Texas. In LCRA Annual Report of Cultural Resources Investigations for 2010. Annual Report No. 20. Lower Colorado River Authority, Austin. 
Quigg, J. Michael, and Jay Peck

1995 The Rush Site (41TG346) A Stratified Late Prehistoric Locale in Tom Green County, Texas. Technical Report No. 816C. Mariah Associates, Inc., Austin.

Quigg, J. Michael, Jeffrey D. Owens, Paul M. Matchen, Grant D. Smith, Robert A. Ricklis, Mercedes C. Cody, and Charles D. Frederick

2008 The Varga Site: A Multicomponent, Stratified Campsite in the Canyonlands of Edwards County, Texas Vol. I. Department of Transportation, Environmental Affairs Department, Archeological Studies Program, Report 110.

Reimer, Paula J., Edouard Bard, Alex Bayliss, J. Warren Beck, Paul G. Blackwell, Christopher Bronk Ramsey, Caitlin E Buck, Hai Cheng, R. Lawrence Edwards, Michael Friedrich, Pieter M. Grootes, Thomas P. Guilderson, Haflidi Haflidason, Irka Hajdas, Christine Hatté, Timothy J. Heaton, Dirk L Hoffmann, Alan G Hogg, Konrad A. Hughen, K. Felix Kaiser, Bernd Kromer, Sturt W Manning, Mu Niu, Ron W Reimer, David A. Richards, E. Marian Scott, John R. Southon, Richard A. Staff, Christian S. M. Turney, Johannes van der Plicht

2013 IntCal13 and Marine 13 Radiocarbon Age Calibration Curves 90-50,00 Years Cal BP. Radiocarbon 55(4):1869-1887

Rice, Pridence M.

1987 Pottery Analysis: A Sourcebook. The University of Chicago Press. Chicago and London.

Riemenschneider, Larry

1996 The Davis Hackberry Spring Site (41ST87), Sterling County, Texas. The Cache: Collected Papers of Texas Archeology 3:13-26.

Ricklis, Robert A.

1994 Toyah Components: Evidence For Occupation in the Project Area During the Latter Part of the Prehistoric Period. In Archaic and Late Prehistoric Human Ecology in the Middle Onion Creek Valley, Hays County, Texas, by Robert A. Ricklis and Michael B. Collins, pp. 207-316. Studies in Archeology 19. Texas Archeological Research Laboratory, The University of Texas at Austin.

Rush, Haley

2013 The Rowe Valley Site (41wm437): A Study Of Toyah Period Subsistence Strategies In Central Texas. MA Thesis, Texas State University.

Shafer, Harry J.

2006 People of the Prairie: A Possible Connection to the Davis Site Caddo. Texas Department of Transportation and Prewitt and Associates, Inc., Austin.

Sackett, James R.

1985 Style and Ethnicity in the Kalahari: A Reply to Wiessner. American Antiquity 50(1):154-159. 
1990 Style and ethnicity in archaeology: the case for isochrestism, In The Uses of Style in Archaeology, M. W. Conkey and C. A. Hastorf, Eds., pp. 32-43, Cambridge University Press, Cambridge, UK, 1990.

Schiffer, Michael B.

1986 Radiocarbon dating and the "old wood" problem: The case of the Hohokam chronology. Journal of Archaeological Science, 13:13-30.

Speth, John D. and Khori Newlander

2012 Plains-Pueblo Interaction: A View from the "Middle." In The Toyah Phase of Central Texas, Late Prehistoric Economic and Social Processes, edited by Nancy A. Kenmotsu and Douglas K. Boyd, pp. 152-180. Texas A\&M University Press, College Station.

Talma, A. S. and J. C. Vogel

1993 A simplified Approach to Calibrating C14 Dares. Radiocarbon 35(2):317-322.

Thompson, Jennifer L., Raymond P. Mauldin, Steve A. Tomka, and Eric Oksanen

2012 Archeological Testing and Data Recovery at the Flatrock Road Site, 41KM69, Kimble County, Texas. Center for Archaeological Research The University of Texas at San Antonio, Archaeological Report, No. 419. Prepared for Environmental Affairs Division, Texas Department of Transportation, Archeological Studies Program, Report No. 133.

Tomka, Steve A.

1999 Historic Period Lithic Technology at Mission San Jose y San Miguel De Aguayo. Bulletin of the Texas Archeological Society 70:241-263.

Treece, A.C., C. Lintz, W.N. Trierweiler, J.M. Quigg, and K.A. Miller

1993 Cultural Resources Investigations in the O.H. Ivie Reservoir, Concho, Coleman, and Runnels Counties, Texas. Vol. IV Data Recovery from Ceramic Sites. Technical Report 346-IV, Austin, Texas Mariah Associates.

Turner, Ellen S., Thomas. R. Hester, and Richard L. McReynolds

2011 Stone Artifacts of Texas Indians. Taylor Trade Publishing, New York.

Vehik, Susan C.

2002 Conflict, Trade, and Political Development on the Southern Plains. American Antiquity 67(1):37-64.

Wade, Mariah

2003 Native Americans of the Texas Edwards Plateau, 1582 - 1799. University of Texas Press, Austin.

Walter, Tamra L.

2004 The Archaeology of Presidio San Saba: A Preliminary Report. Historical Archaeology Vol. 38, No. 3, Presidios of the North American Spanish Borderlands (2004), pp. 94-105. 
Weissner, Polly

1983 Style and Social Information in Kalahari San Projectile Points. American Antiquity 48:253276.

Whittaker, John C.

1994 Flintknapping: Making and Understanding Stone Tools. University of Texas Press, Austin.

Wilson, Moira A., Andrea Hamilton, Ceren Ince, Margaret A. Carter, and Christopher Hall

2012 Rehydroxylation (RHX) dating of archaeological pottery. Published 12 July 2012.DOI:

10.1098/rspa.2012.0109.

http://rspa.royalsocietypublishing.org/content/early/2012/07/11/rspa.2012.0109

Wobst. H. Martin

1977 Stylistic Behavior and Information Exchange. In Papers for the Director: Research Essays in Honor of James B. Griffin, edited by Charles E. Cleland. Anthropology Papers. 61:317-342.

Museum of Anthropology. University of Michigan. Ann Arbor.

\title{
APPENDIX: \\ LUMINESCENCE ANALYSIS OF POTTERY FROM CENTRAL TEXAS
}

\author{
By James K. Feathers \\ Luminescence Dating Laboratory \\ University of Washington
}

This report presents the results of luminescence analysis on 3 small ceramic pieces collected from the surface of a small site on a high Pleistocene terrace of the San Saba River across the river from the town of the same name. The samples were submitted by Charles Hixson of Kingsland, TX. Because the samples were so small, they were combined as one sample for the purpose of luminescence analysis, although it is not known if they came from the same original vessel. The sample (SanSaba 11.17.12.1) was given the lab number UW3087. Laboratory procedures are given in the concluding section.

\section{Dose Rate}

The dose rate was measured on the bulk ceramics and on an associated sediment collected from the center of the site within $15 \mathrm{~m}$ of the sherd locations. Dose rates were mainly determined using alpha counting and flame photometry. The beta dose rate calculated from these measurements on the ceramics was compared with the beta dose rate measured directly by beta counting. These were within 1-sigma error terms, $2.82 \pm 0.24 \mathrm{~Gy} / \mathrm{ka}$ from beta counting, and $2.83 \pm 0.07$ for alpha counting/flame photometry. Moisture content was estimated at about $10 \%$ for the ceramic, reflecting arid conditions, and $20 \%$ for the clay loam sediment. Table A-1 gives the radioactivity data and the dose rates. 
Table A-1. Radionuclide concentrations.

\begin{tabular}{|c|c|c|c|c|c|}
\hline Sample & 238U (ppm) & 233Th (ppm) & K (\%) & & \\
\hline UW3087 & $2.54 \pm 0.18$ & $7.83 \pm 0.96$ & $2.74 \pm 0.07$ & & \\
\hline sediment & $0.70 \pm 0.16$ & $14.39 \pm 1.56$ & $1.55 \pm 0.06$ & & \\
\hline UW3087 & $\begin{array}{l}\text { Alpha (Gy/ka) } \\
0.71 \pm 0.09\end{array}$ & $\begin{array}{l}\text { Beta (Gy/ka) } \\
2.51 \pm 0.18\end{array}$ & $\begin{array}{l}\text { Gamma (Gy/ka) } \\
0.43 \pm 0.12\end{array}$ & $\begin{array}{l}\text { Cosmic (Gy/ka) } \\
0.23 \pm 0.05\end{array}$ & $\begin{array}{l}\text { Total (Gy/ka) } \\
3.88 \pm 0.24\end{array}$ \\
\hline
\end{tabular}

\section{Equivalent Dose}

Equivalent dose was measured for TL, OSL and IRSL as described in the appendix. The TL plateau was relatively broad $\left(250-320^{\circ} \mathrm{C}\right)$. There was no significant sensitivity change with heating. TL anomalous fading was evident (g-value of about 3.4\%), although not much data were available for assessment because of the small size of the sherds.

OSL/IRSL was measured on 6 aliquots. Scatter was minimal (over-dispersion of only $12 \pm 6 \%$ ). The IRSL signal was weak, although the OSL signal was only twice as large in intensity. IRSL stems from feldspars, which are prone to anomalous fading. A relatively large IRSL signal may suggest the OSL signal partly stems from feldspars and therefore may fade, so a weak IRSL suggests the OSL is dominated by quartz. The OSL $b$-value, which is a measure of the efficiency of alpha radiation in producing luminescence as compared to beta and gamma radiation, is a little higher than normal for quartz, however. As a test of the SAR procedures, a dose recovery test was performed. The recovered dose $(51.3 \pm 5.2 \mathrm{~s} ß)$ was a little higher than the given dose $(40 \mathrm{~s} ß)$, so the OSL equivalent dose could be a little over-estimated. Equivalent dose and b-values for TL and OSL are given in Table A-2.

Table A-2. Equivalent dose and b-value - fine grains.

\begin{tabular}{lllllll}
\hline Sample & \multicolumn{3}{c}{ Equivalent dose (Gy) } & \multicolumn{3}{c}{ b-value (Gy $\left.\boldsymbol{\mu m}^{2}\right)$} \\
& TL & IRSL & OSL & TL & IRSL & OSL \\
\hline UW3087 & $2.54 \pm 0.28$ & $8.95 \pm 2.26$ & $3.88 \pm 0.24$ & $1.68 \pm 0.16$ & $1.53 \pm 0.21$ & $1.00 \pm 0.09$ \\
\hline
\end{tabular}

\section{Age}

Ages for TL and OSL are given in Table A-3. Notice that they are not in agreement. The TL age is under-estimated if anything, because the fading correction was not based on sufficient data. The OSL age, on the other hand, is usually more reliable, but could possibly be over-estimated because the dose recovery test over-estimated the given dose. The best estimate is somewhere between the two. The age was also calculated using only $3 \%$ moisture for the ceramic and $10 \%$ for the sediment, but it decrease the OSL age by only 70 years.

Table A-3. Age of UW3087.

\begin{tabular}{llll}
\hline Sample & Age (ka) & \% error & Calendar date \\
\hline TL & $0.67 \pm 0.09$ & 13.1 & AD 1350 90 \\
OSL & $1.00 \pm 0.09$ & 9.4 & AD 1020 \pm 90 \\
\hline
\end{tabular}




\section{Procedures for Thermoluminescence Analysis of Pottery}

\section{Sample Preparation-Fine Grain}

The sherd is broken to expose a fresh profile. Material is drilled from the center of the crosssection, more than $2 \mathrm{~mm}$ from either surface, using a tungsten carbide drill tip. The material retrieved is ground gently by an agate mortar and pestle, treated with $\mathrm{HCl}$, and then settled in acetone for 2 and 20 minutes to separate the $1-8 \mu \mathrm{m}$ fraction. This is settled onto a maximum of 72 stainless steel discs.

\section{Glow-outs}

Thermoluminescence is measured by a Daybreak reader using a $9635 \mathrm{Q}$ photomultiplier with a Corning 7-59 blue filter, in $\mathrm{N}_{2}$ atmosphere at $1^{\circ} \mathrm{C} / \mathrm{s}$ to $450^{\circ} \mathrm{C}$. A preheat of $240^{\circ} \mathrm{C}$ with no hold time precedes each measurement. Artificial irradiation is given with a ${ }^{241} \mathrm{Am}$ alpha source and a ${ }^{90} \mathrm{Sr}$ beta source, the latter calibrated against a ${ }^{137} \mathrm{Cs}$ gamma source. Discs are stored at room temperature for at least one week after irradiation before glow out. Data are processed by Daybreak TLApplic software.

\section{Fading Test}

Several discs are used to test for anomalous fading. The natural luminescence is first measured by heating to $450^{\circ} \mathrm{C}$. The discs are then given an equal alpha irradiation and stored at room temperature for varied times: $10 \mathrm{~min}, 2$ hours, 1 day, 1 week and 8 weeks. The irradiations are staggered in time so that all of the second glows are performed on the same day. The second glows are normalized by the natural signal and then compared to determine any loss of signal with time (on a log scale). If the sample shows fading and the signal versus time values can be reasonably fit to a logarithmic function, an attempt is made to correct the age following procedures recommended by Huntley and Lamothe (2001). The fading rate is calculated as the g-value, which is given in percent per decade, where decade represents a power of 10 .

\section{Equivalent Dose}

The equivalent dose is determined by a combination additive dose and regeneration (Aitken 1985). Additive dose involves administering incremental doses to natural material. A growth curve plotting dose against luminescence can be extrapolated to the dose axis to estimate an equivalent dose, but for pottery this estimate is usually inaccurate because of errors in extrapolation due to nonlinearity. Regeneration involves zeroing natural material by heating to $450^{\circ} \mathrm{C}$ and then rebuilding a growth curve with incremental doses. The problem here is sensitivity change caused by the heating. By constructing both curves, the regeneration curve can be used to define the extrapolated area and can be corrected for sensitivity change by comparing it with the additive dose curve. This works where the shapes of the curves differ only in scale (i.e., the sensitivity change is independent of dose). The curves are combined using the "Australian slide" method in a program developed by David Huntley of Simon Fraser University (Prescott et al. 1993). The equivalent dose is taken as the horizontal distance between the two curves after a scale adjustment for sensitivity change. Where the growth curves are not linear, they are fit to quadratic functions. Dose increments (usually five) are determined so that the maximum additive dose results in a signal about three times that of the natural and the maximum regeneration dose about five times the natural. If the regeneration curve has a significant 
negative intercept, which is not expected given current understanding, the additive dose intercept is taken as the best, if not fully reliable approximation.

A plateau region is determined by calculating the equivalent dose at temperature increments between $240^{\circ}$ and $450^{\circ} \mathrm{C}$ and determining over which temperature range the values do not differ significantly. This plateau region is compared with a similar one constructed for the b-value (alpha efficiency), and the overlap defines the integrated range for final analysis.

\section{Alpha Effectiveness}

Alpha efficiency is determined by comparing additive dose curves using alpha and beta irradiations. The slide program is also used in this regard, taking the scale factor (which is the ratio of the two slopes) as the b-value (Aitken 1985).

\section{Radioactivity}

Radioactivity is measured by alpha counting in conjunction with atomic emission for ${ }^{40} \mathrm{~K}$. Samples for alpha counting are crushed in a mill to flour consistency, packed into plexiglass containers with ZnS:Ag screens, and sealed for one month before counting. The pairs technique is used to separate the $U$ and $T h$ decay series. For atomic emission measurements, samples are dissolved in HF and other acids and analyzed by a Jenway flame photometer. K concentrations for each sample are determined by bracketing between standards of known concentration. Conversion to ${ }^{40} \mathrm{~K}$ is by natural atomic abundance. Radioactivity is also measured, as a check, by beta counting, using a Risø low level beta GM multicounter system. About $0.5 \mathrm{~g}$ of crushed sample is placed on each of four plastic sample holders. All are counted for 24 hours. The average is converted to dose rate following Bøtter-Jensen and Mejdahl (1988) and compared with the beta dose rate calculated from the alpha counting and flame photometer results.

Both the sherd and an associated soil sample are measured for radioactivity. Additional soil samples are analyzed where the environment is complex, and gamma contributions determined by gradients (after Aitken 1985: appendix H). Cosmic radiation is determined after Prescott and Hutton (1988). Radioactivity concentrations are translated into dose rates following Guérin et al. (2011).

\section{Moisture Contents}

Water absorption values for the sherds are determined by comparing the saturated and dried weights. For temperate climates, moisture in the pottery is taken to be $80 \pm 20$ percent of total absorption, unless otherwise indicated by the archaeologist. Again for temperate climates, soil moisture contents are taken from typical moisture retention quantities for different textured soils (Brady 1974: 196), unless otherwise measured. For drier climates, moisture values are determined in consultation with the archaeologist. 


\section{Procedures for Optically Stimulated or Infrared Stimulated Luminescence of Fine-grained Pottery}

Optically stimulated luminescence (OSL) and infrared stimulated luminescence (IRSL) on finegrain $(1-8 \mu \mathrm{m})$ pottery samples are carried out on single aliquots following procedures adapted from Banerjee et al. (2001) and Roberts and Wintle (2001. Equivalent dose is determined by the singlealiquot regenerative dose (SAR) method (Murray and Wintle 2000).

The SAR method measures the natural signal and the signal from a series of regeneration doses on a single aliquot. The method uses a small test dose to monitor and correct for sensitivity changes brought about by preheating, irradiation or light stimulation. SAR consists of the following steps: 1) preheat, 2) measurement of natural signal (OSL or IRSL), L(1), 3) test dose, 4) cut heat, 5) measurement of test dose signal, $\mathrm{T}(1), 6)$ regeneration dose, 7) preheat, 8) measurement of signal from regeneration, $\mathrm{L}(2)$, 9) test dose, 10) cut heat, 11) measurement of test dose signal, $\mathrm{T}(2)$, 12) repeat of steps 6 through 11 for various regeneration doses. A growth curve is constructed from the $\mathrm{L}(\mathrm{i}) / \mathrm{T}$ (i) ratios and the equivalent dose is found by interpolation of $\mathrm{L}(1) / \mathrm{T}(1)$. Usually a zero regeneration dose and a repeated regeneration dose are employed to insure the procedure is working properly. For fine-grained ceramics, a preheat of $240^{\circ} \mathrm{C}$ for $10 \mathrm{~s}$, a test dose of $3.1 \mathrm{~Gy}$, and a cut heat of $200^{\circ} \mathrm{C}$ are currently being used, although these parameters may be modified from sample to sample.

The luminescence, L(i) and T(i), is measured on a Risø TL-DA-15 automated reader by a succession of two stimulations: first $100 \mathrm{~s}$ at $60^{\circ} \mathrm{C}$ of IRSL (880nm diodes), and then $100 \mathrm{~s}$ at $125^{\circ} \mathrm{C}$ of OSL (470nm diodes). Detection is through $7.5 \mathrm{~mm}$ of Hoya U340 (ultra-violet) filters. The two stimulations are used to construct IRSL and OSL growth curves, so that two estimations of equivalent dose are available. Anomalous fading usually involves feldspars and only feldspars are sensitive to IRSL stimulation. The rationale for the IRSL stimulation is to remove most of the feldspar signal, so that the subsequent OSL (post IR blue) signal is free from anomalous fading. However, feldspar is also sensitive to blue light $(470 \mathrm{~nm})$, and it is possible that IRSL does not remove all the feldspar signal. Some preliminary tests in our laboratory have suggested that the OSL signal does not suffer from fading, but this may be sample specific. The procedure is still undergoing study.

A dose recovery test is performed by first zeroing the sample by exposure to light and then administering a known dose. The SAR protocol is then applied to see if the known dose can be obtained.

Alpha efficiency will surely differ among IRSL, OSL and TL on fine-grained materials. It does differ between coarse-grained feldspar and quartz (Aitken 1985). Research is currently underway in the laboratory to determine how much $b$-value varies according to stimulation method. Results from several samples from different geographic locations show that OSL $b$-value is less variable and centers around 0.5. IRSL $b$-value is more variable and is higher than that for OSL. TL $b$-value tends to fall between the OSL and IRSL values. We currently are measuring the b-value for IRSL and OSL by giving an alpha dose to aliquots whose luminescence have been drained by exposure to light. An equivalent dose is determined by SAR using beta irradiation, and the beta/alpha equivalent dose ratio 
is taken as the b-value. A high OSL b-value is indicative that feldspars might be contributing to the signal and thus subject to anomalous fading.

\section{Age and Error Terms}

The age and error for both OSL and TL are calculated by a laboratory constructed spreadsheet, based on Aitken (1985). All error terms are reported at 1-sigma. The reference for ka (thousand years before present) is 2010 .

\section{References}

Aitken, M. J.

1985 Thermoluminescence Dating, Academic Press, London.

Banerjee, D., Murray, A. S., Bøtter-Jensen, L., and Lang, A.

2001 Equivalent dose estimation using a single aliquot of polymineral fine grains. Radiation Measurements 33:73-93.

Bøtter-Jensen, L, and Mejdahl, V.

1988 Assessment of beta dose-rate using a GM multi-counter system. Nuclear Tracks and Radiation Measurements 14:187-191.

Brady, N. C.

1974 The Nature and Properties of Soils, Macmillan, New York.

Galbraith, R. F., and Roberts, R. G.

2012 Statistical aspects of equivalent dose and error calculation and display in OSL dating: an overview and some recommendations. Quaternary Geochronology 11:1-27

Guérin, G., Mercier, N., and Adamiec, G.

2011 Dose-rate converstion factors: update. Ancient TL 29:5-8.

Huntley, D. J., and Lamothe, M.

2001 Ubiquity of anomalous fading in K-feldspars, and measurement and correction for it in optical dating. Canadian Journal of Earth Sciences 38:1093-1106.

Murray, A. S., and Wintle, A. G.

2000 Luminescence dating of quartz using an improved single-aliquot regenerative-dose protocol. Radiation Measurements 32:57-73.

Prescott, J. R., Huntley, D. J., and Hutton, J. T.

1993 Estimation of equivalent dose in thermoluminescence dating - the Australian slide method. Ancient TL 11:1-5. 
Prescott, J. R., and Hutton, J. T.

1988 Cosmic ray and gamma ray dose dosimetry for TL and ESR. Nuclear Tracks and Radiation Measurements 14:223-235.

Roberts, H. M., and Wintle, A. G.

2001 Equivalent dose determinations for polymineralic fine-grains using the SAR protocol: application to a Holocene sequence of the Chinese Loess Plateau. Quaternary Science Reviews 20:859-863.

Wintle, A. G., and Murray, A. S.

2006 A review of quartz optically stimulated luminescence characteristics and their relevance in single-aliquot regeneration dating protocols. Radiation Measurements 41:369-391. 